\title{
Making Space for Writing: Makerspace Activities and Academic Language in a Middle School Science Classroom
}

\author{
Ashley Stewart \\ aking16@mix.wvu.edu
}

Follow this and additional works at: https://researchrepository.wvu.edu/etd

Part of the Science and Mathematics Education Commons, and the Secondary Education Commons

\section{Recommended Citation}

Stewart, Ashley, "Making Space for Writing: Makerspace Activities and Academic Language in a Middle School Science Classroom" (2020). Graduate Theses, Dissertations, and Problem Reports. 7923.

https://researchrepository.wvu.edu/etd/7923

This Dissertation is protected by copyright and/or related rights. It has been brought to you by the The Research Repository @ WVU with permission from the rights-holder(s). You are free to use this Dissertation in any way that is permitted by the copyright and related rights legislation that applies to your use. For other uses you must obtain permission from the rights-holder(s) directly, unless additional rights are indicated by a Creative Commons license in the record and/ or on the work itself. This Dissertation has been accepted for inclusion in WVU Graduate Theses, Dissertations, and Problem Reports collection by an authorized administrator of The Research Repository @ WVU.

For more information, please contact researchrepository@mail.wvu.edu. 
Making Space for Writing: Makerspace Activities and Academic Language in a Middle School Science Classroom

Ashley Stewart

Dissertation submitted

to the College of Education and Human Services

at West Virginia University

in partial fulfillment of the requirements for the degree of

Doctor of Education in

Instructional Design and Technology

Jiangmei Yuan, Ph.D., Chair

Ugur Kale, Ph.D.

Keri Valentine, Ph.D.

Monica McCartney, Ed.D.

Department of Learning Sciences and Human Development

\author{
Morgantown, West Virginia \\ 2020
}

Keywords: instructional design, makerspace, academic language, motivation

Copyright 2020 Ashley Stewart 


\begin{abstract}
Making Space for Writing: Makerspace Activities and Academic Language in a Middle School Science Classroom
\end{abstract}

\begin{abstract}
Ashley Stewart
Over recent decades, the maker movement has expanded from the private sector, libraries, and higher education institutions to K-12 schools. While many studies provide implications of STEM and maker activities and their effects on learning in informal settings, few have framed such investigations within the context of a makerspace in K-12 schools. Furthermore, few have investigated maker activities and writing, particularly in developing academic language features. Prior research suggests that secondary students struggle to apply academic language features. Meanwhile, they are motivated to engage in STEM and maker activities. This mixed methods case study attempted to make a connection between makerspaces and academic language. The study examined the effect of collaboration and space on middle school students' motivation and academic language in a science classroom as students engaged in maker activities. Findings indicated that students enjoyed working in makerspaces and that collaboration, which was determined by role assignments in groups, reduced students' sense of pressure, but no other subscale of motivation. Collaboration did not affect academic writing quality. Space had no effect on either motivation or writing. However, all groups' writing scores increased following the intervention.
\end{abstract}




\section{DEDICATION}

This dissertation is dedicated to my sons

Felix and Finn

whose constant curiosity and exploration inspire my own 


\section{ACKNOWLEDGEMENTS}

I would like to acknowledge my husband, Craig, who unfailingly supported me from the moment that I submitted my program application. To my parents, Steve and Debbie, who provided countless hours of childcare — and reassurance. To the faculty members who guided me through this process. To my advisor, Dr. Yuan, who tirelessly worked with me every week and who kept me on a realistic schedule. To Dr. Kale, who offered meaningful insight to the design. To Dr. McCartney, who always suggested effective instructional approaches. To Dr. Valentine, who provided a valuable perspective from the field. To the Roger McAvoy Scholarship Foundation and to Dr. Huntington, who graciously gave financial support. And finally, to Dr. Ahern, who consistently showed up to my classroom to convince me to become a doctor. Even after he left us, his persistence encouraged me to continue with this project. 
Table of Contents

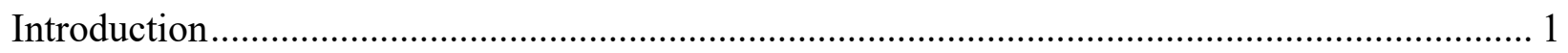

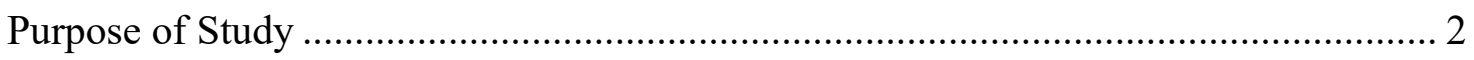

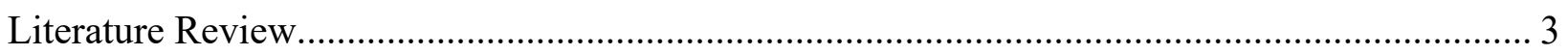

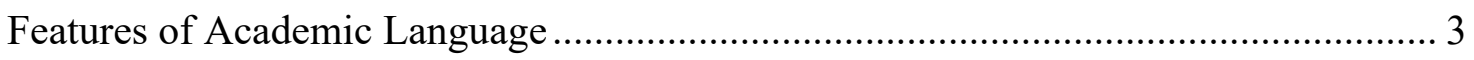

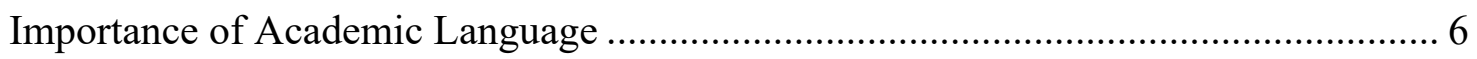

Students' Struggle with Academic Language ............................................................ 8

Strategies to Improve Students' Academic Writing.................................................... 8

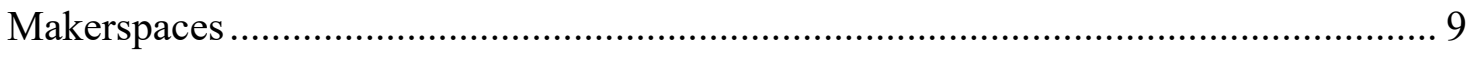

Makerspaces and Academic Writing....................................................................... 12

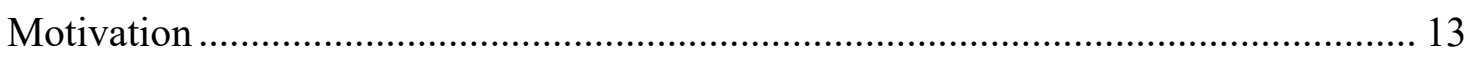

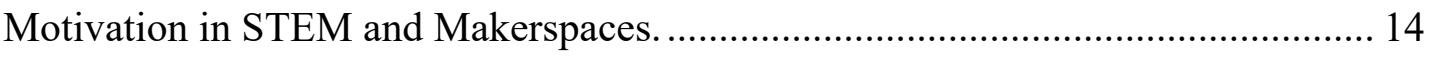

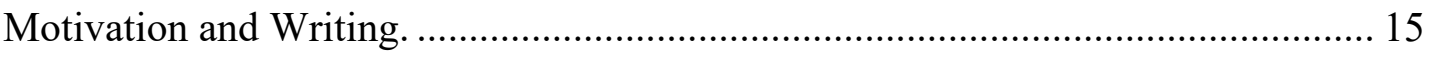

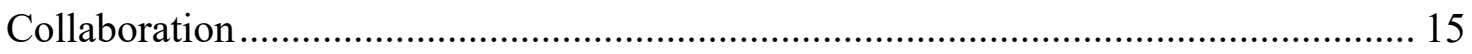

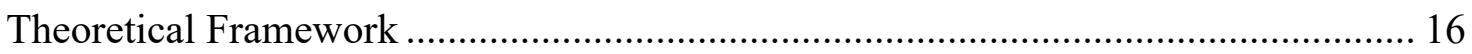

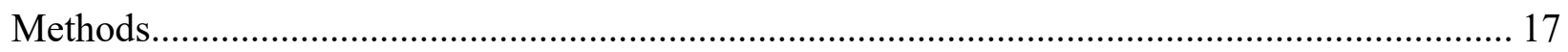

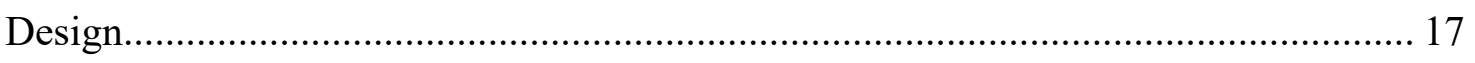

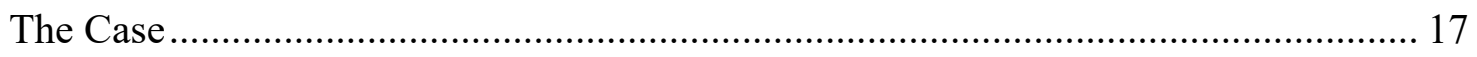

Embedded Units Within the Case ......................................................................... 19

Subunit 1: Assigned Roles Makerspace. ........................................................ 20

Subunit 2: Assigned Roles Classroom. ................................................................. 20

Subunit 3: No Roles Makerspace. ..................................................................... 21

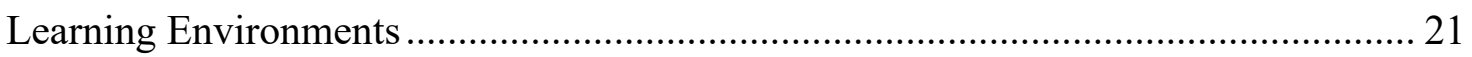

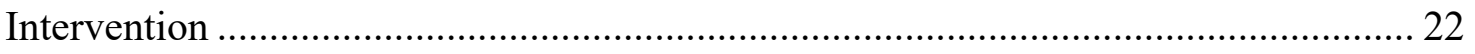

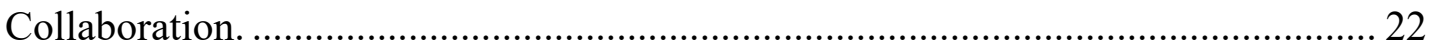

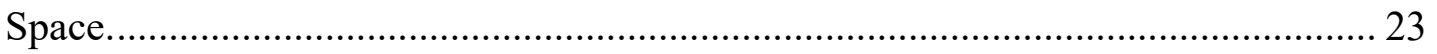

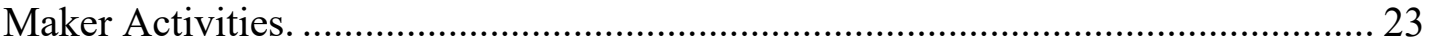

Data Collection Procedure .................................................................................... 28

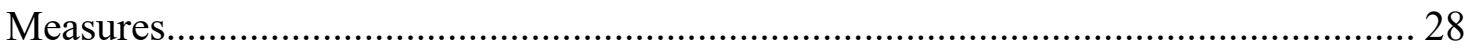

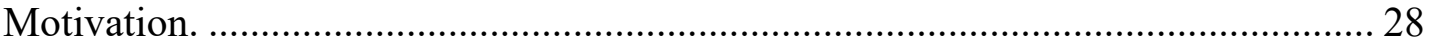

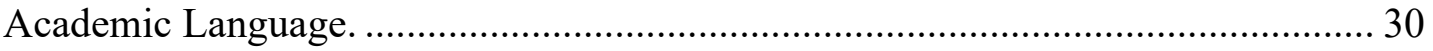

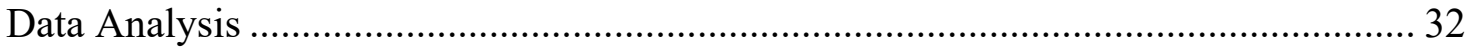

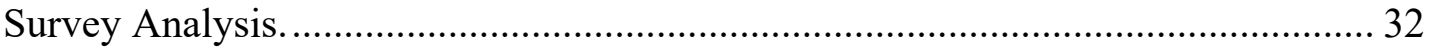




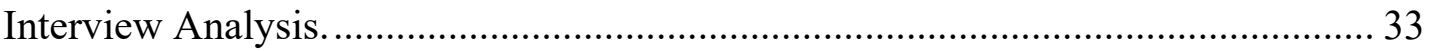

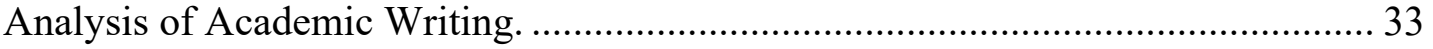

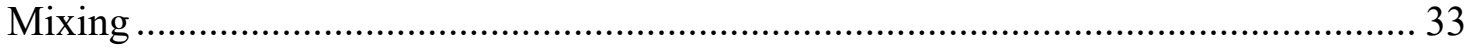

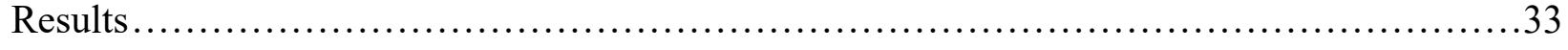

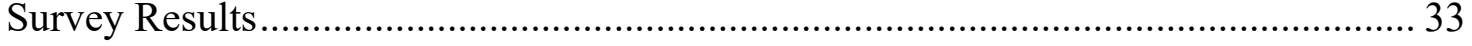

Pre- and Post-Writing Scores .................................................................... 35

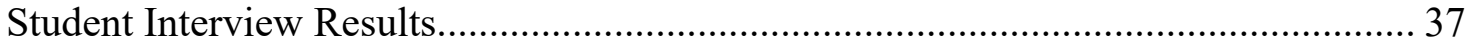

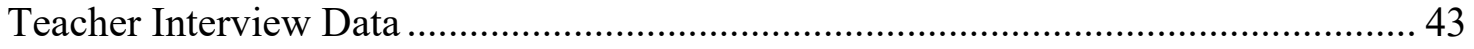

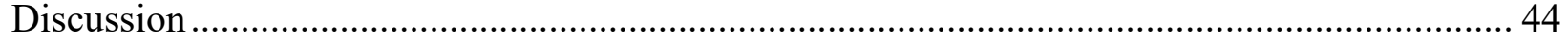

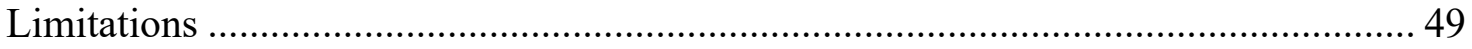

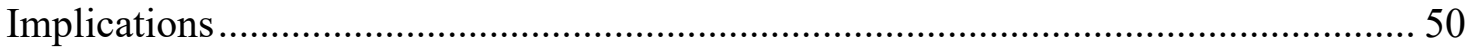

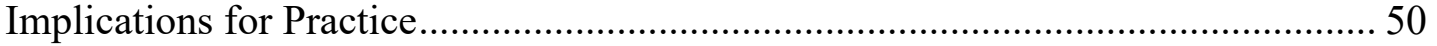

Implications for Future Research .................................................................. 51

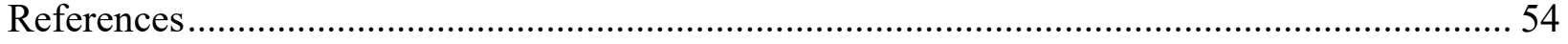

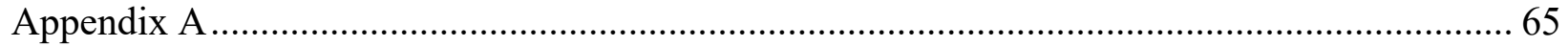

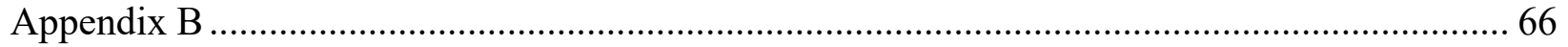

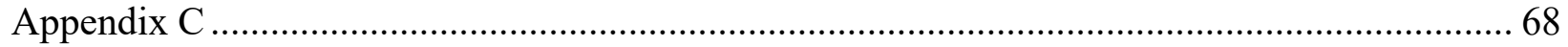

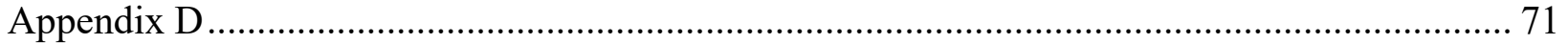




\section{LIST OF TABLES}

Table 1: Features of Academic Language..............................3

Table 2: Demographics of Participants...........................19

Table 3: Embedded Units within in the Case........................20

Table 4: Role Assignments for Groups within Assigned Roles Subunits..23

Table 5: Purpose and Rationale of Maker Activities......................24

Table 6: Scientific Writing Rubric................................... 30

Table. 7: Descriptive Statistics of Survey Results by Subunit.............34

Table 8: One-Way ANOVA Results of Survey.........................34

Table 9: Planned Comparisons of One-Way ANOVA Survey Results....35

Table 10: Descriptive Statistics of Writing Results by Subunit............36

Table 11: Paired-Samples $t$-Test Results of Pre- and Post-Writing by Subunit...37 
Making Space for Writing: Makerspace Activities and Academic Language in a Middle School Science Classroom

\section{Introduction}

In its written form, academic language is a complex construct involving high-level cognitive skills (Olinghouse \& Wilson, 2013). Though academic language is commonly associated with vocabulary (Uccelli, Galloway, et al., 2015), its components include nuances of syntax and organizational devices, which differ from conversational speech. Due to such complexities and differences, mastering written academic language can present challenges to adolescents as they engage in the writing process of brainstorming, drafting, revising, editing, and publishing (Fang \& Park, 2019; Kobayashi et al., 2017). Adolescents' struggle with academic writing consequently presents challenges for teachers, especially in content areas outside of English Language Arts in which teachers feel underprepared in teaching writing (Ray, Graham, Houston, \& Harris, 2016; Snow, 2010).

As a non-language arts subject, science is a content area that is commonly grouped with mathematics and technology through the STEM (science, technology, engineering, and mathematics) movement. This movement particularly highlights the nature of scientific inquiry by emphasizing the engineering design process of empathizing, defining, ideating, prototyping, and evaluating. However, science is strongly tied to English Language Arts through the Next Generation Science Standards; each topic in secondary science (e.g., Matter and Energy in Organisms and Ecosystems, Earth's Systems, and Human Impact) includes English Language Arts and literacy learning goals that focus on reading and writing skills. While the engineering design cycle and the writing process mirror one another as iterative cycles, the disconnect 
between the two seem wide as some science teachers lack confidence in incorporating instructional writing strategies into the curriculum (Snow, 2010).

As a common learning context for promoting science and the engineering design cycle, makerspaces have become more prevalent in educational institutions (Freeman et al., 2017). Within makerspaces, students work individually or collaboratively to design and create artifacts, either with software or with physical objects. However, makerspaces may also serve as effective learning environments for engaging in other iterative cycles, such as the writing process (Tham, 2019). Similar to how makerspaces foster student interaction with the engineering design process to create a physical product, makerspaces may also foster student interaction with the writing process to create a written piece. Through "tinkering," or practicing (Chai \& Welz, 2018), with words, students may engage with language through tangible resources to produce an artifact, or written product. However, more research is needed to make this connection. The purpose of this study was to add to the growing body of literature to attempt to bridge this gap.

\section{Purpose of Study}

The purpose of this study was to examine the impacts that makerspace activities have on the development of written academic language among middle schoolers in a science classroom. While maker education research has focused on various fields within the sciences, the research has stopped short of developing scientific writing, though an important skill for learning (Balgopal \& Wallace, 2013; Gere et al., 2019; Sampson et al., 2013). This study was intended to fill the gap in the existing literature. The following research questions were central to this study:

1. How did the space of a makerspace affect students' motivation to complete a maker activity?

2. How did the space of a makerspace affect the quality of students' academic writing? 
3. How did collaboration within maker activities affect students' motivation to complete a maker activity?

4. How did collaboration within maker activities affect the quality of students' academic writing?

\section{Literature Review}

\section{Features of Academic Language}

Academic language can be described as the language of schooling (Schleppegrell, 2001) or language used in formal settings, such as school and writing (Snow \& Uccelli, 2009). While definitions vary, there are components of academic language that are common among research. These commonalities include lexical choices, complex syntactic structures, organizational strategies, and authoritative indicators (Fang \& Park, 2019; Schleppegrell, 2001; Snow \& Uccelli, 2009; Uccelli, Barr, Dobbs, Galloway, \& Menses., 2015a; Uccelli, Dobbs, \& Scott, 2013). The features of academic language are presented in Table 1.

Table 1

Features of Academic Language

\begin{tabular}{llll}
\hline \multicolumn{1}{c}{ Feature } & & \multicolumn{1}{c}{ Description } & \multicolumn{1}{c}{ Example } \\
\hline $\begin{array}{l}\text { Lexical } \\
\text { choices }\end{array}$ & $\begin{array}{l}\text { Content } \\
\text { vocabulary }\end{array}$ & Domain-specific terms & Polymer, hydrocarbon \\
\cline { 2 - 4 } & $\begin{array}{l}\text { Academic } \\
\text { vocabulary }\end{array}$ & Terms used across domains & Synthesize, phenomenon \\
\cline { 2 - 4 } & Lexically dense & High proportion of nouns, & $\begin{array}{l}\text { The multiple components of the } \\
\text { nuanced project complicate the } \\
\text { process. }\end{array}$ \\
& terms & verbs, or modifiers & Cognizant, benefactor \\
\cline { 2 - 4 } & Complex & Multisyllabic words with roots \\
& and affixes & \\
\hline
\end{tabular}




\begin{tabular}{|c|c|c|c|}
\hline \multirow[t]{5}{*}{$\begin{array}{l}\text { Complex } \\
\text { syntax }\end{array}$} & $\begin{array}{l}\text { Expanded noun } \\
\text { phrases }\end{array}$ & $\begin{array}{l}\text { Phrases with three or more pre- } \\
\text { or post-modifiers of a noun }\end{array}$ & $\begin{array}{l}\text { The last remaining ancient } \\
\text { artifact }\end{array}$ \\
\hline & $\begin{array}{l}\text { Non-restrictive } \\
\text { relative } \\
\text { clauses }\end{array}$ & $\begin{array}{l}\text { Clauses introduced by relative } \\
\text { pronouns following a common } \\
\text { noun }\end{array}$ & $\begin{array}{l}\text { The article, which was } \\
\text { published last year }\end{array}$ \\
\hline & Nonfinite clauses & $\begin{array}{l}\text { Clauses that are introduced by a } \\
\text { tenseless verb }\end{array}$ & $\begin{array}{l}\text { Discovered last century, the } \\
\text { element... }\end{array}$ \\
\hline & Appositives & $\begin{array}{l}\text { Noun or noun phrase that } \\
\text { modifies the preceding noun }\end{array}$ & $\begin{array}{l}\text { The dodo bird, an extinct } \\
\text { species... }\end{array}$ \\
\hline & Nominalization & Nouns that represent a process & Computerization \\
\hline \multirow[t]{2}{*}{$\begin{array}{l}\text { Organizational } \\
\text { strategies }\end{array}$} & Explicit markers & $\begin{array}{l}\text { Words or phrases that organize } \\
\text { information }\end{array}$ & $\begin{array}{l}\text { First..., Second... } \\
\text { In summary... }\end{array}$ \\
\hline & $\begin{array}{l}\text { Discourse } \\
\text { markers }\end{array}$ & $\begin{array}{l}\text { Connectives between } \\
\text { relationships of thought }\end{array}$ & $\begin{array}{l}\text { For example, } \\
\text { Additionally }\end{array}$ \\
\hline $\begin{array}{l}\text { Authoritative } \\
\text { indicators }\end{array}$ & & $\begin{array}{l}\text { Words and phrases that } \\
\text { establish a detached and } \\
\text { authoritative stance }\end{array}$ & $\begin{array}{l}\text { Inarguably } \\
\text { While some may believe... }\end{array}$ \\
\hline
\end{tabular}

As one of the more obvious components of academic language (Schleppegrell, 2001), lexical choices in academic language include general vocabulary and domain-specific vocabulary. The use of specialized terminology has been a strong predictor of students' academic writing quality on elementary, middle school, and high school levels (Fang \& Park, 2019; Olinghouse \& Wilson, 2013), while students struggle to use more general academic vocabulary (Olinghouse \& Wilson, 2013; Snow \& Uccelli, 2009). Students are also exposed to technical and non-technical vocabulary within their school texts (Schleppegrell, 2001). While various terminologies have been used to describe both technical and non-technical lexical items, the terms content vocabulary and academic vocabulary accurately reflect each construct. Content vocabulary (e.g. hydrocarbon, polymer) includes domain-specific words that are unique to certain topics. Academic vocabulary (e.g. optimize, predict), on the other hand, can be used generally across the curricula (Olinghouse \& Wilson, 2013). In addition to the employment of content vocabulary and academic vocabulary, academic language includes lexically dense terms, 
especially including high proportions of nouns, adjectives, and some adverbs in a clause (Schleppegrell, 2001; Uccelli et al., 2013). Additionally, academic language is morphologically complex (Uccelli et al., 2015a). Such complex morphology includes multisyllabic words, which usually containing root words and affixes.

Though content and academic terminologies are important elements of academic language, the construct expands to include more than vocabulary. Lexical choices within academic language can lead to dense morphosyntactic structures (Schleppegrell, 2001; Uccelli et al., 2015a), resulting in complex syntactical structure. Such complex structures include expanded noun phrases (noun phrases with three or more pre- or post-modifiers, e.g., four large wonderous animals); non-restrictive relative clauses (clauses introduced by relative pronouns following a common noun, e.g., the species, which is extinct); nonfinite clauses (clauses that are introduced by a tenseless verb, e.g., Set in the 1900s,); appositives (a noun or noun phrase that modifies the preceding noun, e.g., Black bears, mammals that are prevalent in the area) (Fang \& Park, 2019; Snow \& Uccelli, 2009). Nominalizations, nouns that represent processes, for example computerization, also add to the complexity of syntactic structures of clauses in academic language (Snow \& Uccelli, 2009).

Another notable feature of academic language is the strategies that are employed in order to organize text. Explicit markers are used to organize information, typically in a "stepwise logical argument structure" (Snow \& Uccelli, 2009, p. 120). For example, text can be structured with frame markers (e.g. First..., Second...; One reason is ... Another reason is...) and conclusion markers (e.g. To conclude; In summary) (Uccelli et al., 2013). While these types of markers are not exclusive to academic language, they occur in higher frequency in academic registers (Fang \& Park, 2019; Schleppegrell, 2001). Additionally, discourse markers such as, in 
addition to, although, and for example, serve as connectives between relationship of thought (Snow \& Uccelli, 2009; Uccelli et al., 2015b). Though some researchers consider organizational markers to include connective makers (Schleppegrell, 2001; Uccelli et al., 2013), others make a distinction between the two within academic language. Regardless of the classification of such indicators, connective markers (e.g. meanwhile, furthermore) are frequent features of academic language that contribute to the organization of textual information.

Finally, a significant feature of academic language is the usage of authoritative indicators, which are words and phrases that establish a detached and authoritative stance (Schleppegrell, 2001; Snow \& Uccelli, 2009). Such indicators may include adjectives such as undoubtedly, unlikely, and obviously. These types of makers allow the author to develop an authoritative relationship between the author and audience, as well as establish the writer's viewpoints (Uccelli et al., 2015b). Though epistemic hedges, which mark a degree of uncertainty or lack of authority (e.g. People tend to prefer ...; It is possible that...) (Fang \& Park, 2019), may indicate a lack of authority, they remain authoritative makers as they represent the importance of authoritative voice in academic language.

\section{Importance of Academic Language}

Academic language is an important area of focus in education that has been linked to reading comprehension (Fang \& Park, 2019; McKeown, Crosson, Moore, \& Beck, 2018; Mokhtari \& Velten, 2015; Uccelli et al., 2015b). Both preadolescent and adolescent students who use more features of academic language tend to display higher reading performance levels than students who use such features less frequently (Fang \& Park, 2019). Elementary school and middle school students who have a broad knowledge of general academic vocabulary are also more likely to be higher achieving readers (Uccelli et al., 2015b). Possible suggestions for this 
correlation may be students' amount of exposure to academic language and their ability to recognize key academic vocabulary words (Truckenmiller \& Petscher, 2019; Uccelli et al., 2015b).

In addition to reading comprehension, academic language skills have been linked to preadolescent and adolescent students' writing performance (Fang \& Park, 2019; M. D. Johnson et al., 2016; Olinghouse \& Wilson, 2013; Truckenmiller \& Petscher, 2019). Students who display higher skills in word recognition, vocabulary knowledge, syntactic knowledge, and reading comprehension of academic language are at a lower risk for failing the writing composition segment of state administered tests, whereas students who demonstrate lower skills are more at a risk for failing (Truckenmiller \& Petscher, 2019). Furthermore, students' use of academic language features is a strong predictor of overall informational writing quality (Fang \& Park, 2019) and is correlated with overall academic success (Townsend et al., 2012).

Academic language has a particularly significant role in the science classroom, especially in the form of writing. The national Next Generation Science Standards (NGSSs) include writing objectives for secondary grades, suggesting that students complete organized and stylized pieces of writing with guidance from peers and adults through writing and revision strategies ( $D C I$ Arrangements of the Next Generation Science Standards, 2017). The curricular content standards of this study's setting required that students write explanatory texts, using "precise language and domain-specific vocabulary" in a "formal style and objective tone" ("NxGen Science Standards," n.d., S.6-8.L.12). Not only are such writing skills expected to be developed in the science classroom, they are also beneficial to student learning; writing-to-learn approaches in science result in higher order thinking skills (Prain \& Hand, 1999) and increased knowledge of content (Ray et al., 2016; Sampson et al., 2013). 


\section{Students' Struggle with Academic Language}

As many of its features do not parallel conversational speech, academic language is intrinsically challenging to both native and non-native speakers of English (Snow \& Uccelli, 2009). In the form of writing, preadolescent and adolescent students struggle applying features of academic language in writing (Fang \& Park, 2019; Kobayashi et al., 2017). While adolescents have more positive stances toward writing in English Language Arts classes, they hold more negative perspectives toward writing in social studies, science and math, as they view informative writing as less expressive and subjective (Jeffery \& Wilcox, 2014). In addition, teachers encounter challenges in instruction. Many teachers feel underprepared in supporting student writing, especially teachers of science (Ray et al., 2016; Snow, 2010). While great importance is placed on academic language, little is focused on instruction that directly addresses academic language development.

\section{Strategies to Improve Students' Academic Writing}

In order to achieve effective academic language among secondary students, research suggests implementing strategies that focus on vocabulary and strategies that focus on writing. In robust vocabulary instruction, students should explore vocabulary in order to have the opportunity to discover and "play" with words prior to learning them (Chai \& Welz, 2018). Furthermore, understanding the morphological composition of words is effective for middle school students (Truckenmiller \& Petscher, 2019). While encouraging exploration, practice and application, and morphological analysis, teachers of adolescents should incorporate instructional activities that use pictures to support vocabulary retention, support ongoing review, and allow collaboration increase student engagement and motivation in language instruction (Gallagher \& Anderson, 2016). Effective vocabulary strategies that foster such components include quick 
writes, graffiti walls, pair-shares, video recordings, and picture word walls (Gallagher \& Anderson, 2016; Own, 2018; Townsend, 2015). Similar components of ongoing review and collaboration can also be included in effective writing strategies to develop academic language skills. Such strategies encompass collaborative writing and process writing approaches (Graham \& Perin, 2007). On a sentence-structural level, students should practice combining sentences, particularly using connective discourse markers (Graham \& Perin, 2007; Truckenmiller \& Petscher, 2019).

\section{Makerspaces}

From the 1990s to the early years of the twenty-first century, the term makerspace primarily referred to establishments in the private technology sector or community workshops, intended for adults in engineering-related fields. However, makerspaces entered mainstream education around 2009, most markedly when President Barack Obama called for educators to spend classroom time allowing students "to be makers of things, not just consumers of things" (Revkin, 2009, para. 2). After this event, makerspaces expanded to libraries - those of communities, public schools, and universities. In 2011, dozens of makerspaces were implemented into the Fayetteville Free Library system in New York state, spurring a similar trend across the United States (Hartnett, 2016). Museums serve as another common facility that houses makerspaces, and they have become significant in maker research. The Children's Museum of Pittsburgh, for example, established the MAKESHOP, which has been the site of seminal makerspace studies (e.g. Litts, 2015; Sheridan et al., 2014).

More available to the public, makerspaces have fueled the maker movement, allowing people of all ages to more widely invent, tinker, create, and innovate. The trend has become more predominant in K-12 education during recent years. According to the K-12 2017 Horizon 
Report, makerspaces have been featured as a worldwide technology trend that is anticipated to grow over the next five years in public education (Freeman, Adams Becker, Cummins, \& Hall Giesinger, 2017). The term makerspace in this study refers to a physical space that allows for collaboration, interaction with tangible objects, and engagement in iterative design processes, which result in new skills and/or products.

The value of makerspaces has been reported by many empirical studies. Makerspaces foster diverse learning arrangements as some participants were self-directed, while others attended structured workshops or worked in novice-expert apprenticeships. (Sheridan et al, 2014). Makerspace activities improved community engagement and transformed the library from being a place of user consumption of information into a place of user creation (Slatter and Howard, 2013). The multidisciplinary aspect of makerspaces supports engagement and innovation (Sheridan et al, 2014). Even in informal educational settings, makers showed evidence of learning through their makerspace experiences (Sheridan et al, 2014). Regardless of whether makerspaces are housed in libraries, universities, schools, or museums, initial research on makerspaces focused on the value, obstacles and success of makerspaces. For example, in a public library system, Slatter and Howard (2013) explored the benefits and challenges of makerspaces. Through qualitative interviews, the authors found that makerspace stakeholders believed that makerspaces improved community engagement and transformed the library from being a place of user consumption of information into a place of user creation. However, the authors also discovered obstacles of monetary constraints, resistance within the institutions, and relevance of makerspace in the context of a library. Benjes-Small, Bellamy, Resor-Whicker, and Vassady (2017) also encountered concerns of sustainability in terms of staffing to reduce staff burnout. In the context of a university library, Benjes-Small et al. (2017) investigated common 
indicators of success among 25 academic library makerspaces in the United States through semistructured surveys. While respondents indicated that 21 of the 25 makerspaces were perceived successes, the characteristics of the meaning of success varied. The two most common indicators of success were high usage — primarily reported by art and engineering students — and adequate support through curriculum, courses, and training

The value of makerspaces has also been heavily researched with the framework of promoting science, technology, engineering, and math (STEM) amongst students, families, undergraduates, and communities. As a seminal piece of makerspace literature, a cross comparative case study by Sheridan and colleagues (2014) explored participation, use of equipment, and instructional arrangements among MAKESHOP and two community makerspaces. At all three sites, researchers noted that makerspaces foster diverse learning arrangements as some participants were self-directed, while others attended structured workshops or worked in novice-expert apprenticeships. Additionally, the authors noted that the multidisciplinary aspect of makerspaces support engagement and innovation. Even in informal educational settings, makers displayed learning through experience. Expanding on Sheridan and colleagues' (2014) case study, Litts (2015) examined student learning in makerspaces by utilizing design stances. She affirmed that learning, as well as collaboration, occur naturally in makerspaces.

Furthermore, Litts (2015) identified three primary components of a makerspace: community, space, and tools. Community in a makerspace consists of like-minded thinkers collaborate to "make, create, and hack" (Litts, 2015, p. 5). Space includes the common space in which these thinkers engage, and tools are the resources available in the makerspaces in order to participate in making. 
Litts (2015) investigated a variable that has not been heavily researched within the context of a makerspace: learning, specifically knowledge construction. However, little has been researched on learning within a formal educational environment, especially within K-12 education. Nonetheless, learning in STEM education, which is highly promoted within makerspaces, has been the focus of many studies. Outside of a makerspace environment, researchers have explored the implementation of STEM and engineering design and the impact on student learning (e.g. Burke \& Kafai, 2012; Fields, Kafai, Strommer, Wolf, \& Seiner, 2014; Garneli, Giannakos, Chorianopoulos, \& Jaccheri, 2013). Other studies provide implications of STEM and maker activities and their effects on learning in higher education and informal settings (e.g. Guzey, Ring-Whalen, Harwell, \& Peralta, 2019; Lin, Hsiao, Chang, Chien, \& Wu, 2018; Litts, 2015). Few have framed such investigations within the context of a makerspace in a K-12 educational setting. In addition, research suggests that STEM-related activities enhance the acquisition of skills, such as circuitry and coding (Fields et al., 2014; Kafai et al., 2014), but few studies indicate how makerspace activities affect learning in relation to content standards. As schools rapidly invest in makerspaces, it is imperative to examine student performance and knowledge acquisition that is aligned with content standards.

\section{Makerspaces and Academic Writing}

Making activities, particularly through augmented reality visualizations, can enhance students' academic vocabulary (Own, 2018). Through constructionism, Own (2018) claims that in makerspaces, where students share, create, and participate, students can learn vocabulary by interacting with external artifacts. Extending the connection between making and writing, Tham (2019) recognizes the parallels between design thinking and writing in his case study, in which he applied maker-based pedagogy to a university technical and professional communication 
course. The course's guiding principles were based on three defining characteristics of makerspace activities: tinkering, design thinking, and collaborative learning. Students carried out a design challenge, while producing a piece of writing during each step of the design cycle: empathize, define, ideate, ideate/prototype, and test. Findings suggest that making fosters new literacies, including rhetoric and technical writing.

Though each of these studies serve as a case study with a small sample size, it is worth building on the little research to investigate makerspace's impact on academic writing development. The National Writing Project (NWP) has even recognized the emergent trend of relating maker pedagogy to writing. In 2013, the NWP teamed up with Educator Innovator to produce a series of webinars through Connected Learning TV that apply makerspace literacies to student writing (The Current, 2013). Since 2014, the NWP has also partnered with YOUMedia Learning Labs Network to create interest-driven labs to engage youth in making and doing, (YOUmedia, 2015), concentrating on writing in the maker community. Along with initial research on making and writing, these NWP programs highlight the potential that maker education has to affect students' writing.

\section{Motivation}

Motivation is a construct that has been widely researched in education (e.g. Cleary \& Kitsantas, 2017; Kindermann, 2016; Monteiro et al., 2015; Wentzel, 1998). While various learning and behavior theories frame motivation research (e.g. Bandura, 1986; Vroom, 1995), researchers commonly apply self-determination theory to explore intrinsic motivation (Monteiro et al., 2015). Self-determination theory focuses on the behavior regulation process and internal sources, as well as social contexts, that contribute to its development (Deci, Vallerand, Pelletier, \& Ryan, 1991). This regulatory process is controlled by choice, as opposed to compliance. Self- 
determination theory focuses on three psychological needs: autonomy, competence, and relatedness. As motivation, particularly intrinsic motivation, has been closely tied to student performance and engagement (Deci et al., 1991), self-determination theory provides a framework for exploring motivation in the classroom.

Motivation in STEM and Makerspaces. Surveying more than 50 experimental and quasi-experimental studies exploring student motivation in STEM education, Rosenzweig and Wigfield (2016) concluded that, overall, motivation interventions within STEM education result in students' improvement in competence-related beliefs values, interest, attributions, beliefs about outcomes, and academic performance. While research suggests that motivation can enhance components of STEM education, more recent studies have found that STEM education can improve motivation. LaForce and colleagues (LaForce et al., 2017) found that high school students who were engaged in problem-based learning in the STEM subjects showed higher levels of scientific intrinsic motivation and ability beliefs; however, they did not show higher levels of math intrinsic motivation.

More specifically within the context of a makerspace, Schlegel and colleagues (2019) observed that making-based science curricula resulted in significant increases in elementary students' sense of making self-efficacy, science identity, and possible identifies within STEM, particularly among minority students. Vongkulluksn, Matewos, Sinatra, and March (2018) expanded motivation research on makerspaces by closely examining the motivational variables related to students' interest in design-based learning, particularly in relation to self-efficacy and situational interest. In this longitudinal study among $2^{\text {nd }}$ to $6^{\text {th }}$ grade students, the authors concluded that self-efficacy and situational interest declined over the semester in makerspace. Emotions of excitement were correlated with high levels of self-efficacy, while emotions of 
confusion were correlated with lower levels of self-efficacy. Despite this trend, both self-efficacy and situational interest remained moderately high throughout the study. The authors attributed this to student autonomy and ownership of learning in makerspace activities. As a whole, research suggests that engagement in STEM and makerspace activities can be positively correlated with higher levels of motivation.

Motivation and Writing. Research exploring the role of motivation and writing among students has a longer history. In a review of 16 studies examining the role of self-efficacy in writing among pre-adolescents and adolescents, Klassen (2002) concluded that the majority of studies found that self-efficacy played the primary role in predicting students' writing performance. These findings are congruent to those of the literature review conducted by Pajares (2003), who accumulated findings from the most prominent studies in writing and self-efficacy and determined that self-efficacy and writing performances are positively correlated. More recent research supports such findings, emphasizing the importance of variables of motivation and writing performances among students (Bruning \& Kauffman, 2015; Bruning et al., 2013; van Blankenstein et al., 2019).

\section{Collaboration}

Research has identified collaboration as a foundational element of makerspaces (Bers et al., 2018; Galaleldin et al., 2017; Hsu et al., 2017; Tham, 2019; Wilczynski, 2015). Collaborative learning has been correlated with higher academic achievement (Bertucci et al., 2010; Crawford et al., 1999; Johnson et al., 1994; Slavin, 1991). However, creating an environment in which learners engage in peer interaction, or group work, does not ensure collaboration (Chang \& Brickman, 2018). Collaborative learning is grounded in the social constructivist epistemology and focuses on acculturation into a learning community as opposed to simply completing a task 
(Oxford, 1997). In order to facilitate this process, strategies such as roles assignment, group contracts, peer evaluations, and peer ratings are recommended strategies (Chang \& Brickman, 2018). Though little research has explored collaborative learning within academic makerspaces, these strategies could be applied in such a learning context.

\section{Theoretical Framework}

Emphasizing knowledge construction through social learning, this study is guided by constructionism. As both a learning theory and instructional strategy, constructionism places importance on the context in which the "learner is consciously engaged in constructing a public entity" (Papert, 1991, p. 1). Additionally, Papert emphasizes the role of external artifacts as tangible objects of discussion, examination, and admiration (Papert, 1993).

Centered on the concept of knowledge building, constructionism is rooted in Piagetian theory. Piaget (1954) proposes that knowledge is actively constructed through direct and personal interaction with objects in one's immediate environment. Though a cognitivist, Piaget suggests that learning occurs both within and beyond the learner as knowledge construction "parallels the formation of a world of objects and spatial relationships" in the learner's universe (Piaget, 1954, p. xii). As Piaget's protégé, Papert (1991) expanded on constructivism by acknowledging the role of the learning context, one in which the learner is actively engaged in the construction of concrete, as opposed to abstract, materials. Not only does physical construction contribute to knowledge construction, Papert (1991) suggests that children might become more motivated to learn through building because the work is more authentic and meaningful to the learner. Furthermore, constructionism allows for diversity of intellectual styles and preferences. In its simplest form, constructionism is "learning-by-making" (p. 6), and it has driven research within the maker movement (e.g., Bers, Strawhacker, \& Vizner, 2018; Burke \& 
Kafai, 2012; Kafai, Fields, \& Searle, 2014; Litts, 2015). In a makerspace, when students create artifacts representing a vocabulary or the structure of sentence, they interact with the physical representations of the vocabulary and sentences.

\section{Methods}

\section{Design}

This study was conducted through case study research. Specifically, this study acted as an instrumental case study, which sought to understand a complex phenomenon within a bounded system rather than to understand the case itself (Stake, 1995). In this study, the case was an eighth grade, general science course in a middle school. The researcher acted as the primary instrument of data collection in order to better inform the "how" questions of a phenomenon within a case in (Baxter \& Jack, 2008). This study incorporated "multiple realities" through various data sources from both the teacher and students to provide thick description (Stake, 1995, p. 43).

Case studies can include both quantitative and qualitative research (Merriam, 2009; Stake, 1995). Embedded in this case study was a concurrent triangulation design (Plano Clark \& Creswell, 2008). Quantitative and qualitative data were collected concurrently and analyzed separately. All research questions were explored by gathering both quantitative and qualitative data, and mixing occurred at the interpretation stage. In mixed method studies, equal priority to both quantitative and qualitative data is ideal; however, giving priority to one methodology over the other is acceptable (Plano Clark \& Creswell, 2008). In this study, qualitative data, including transformed qualitative data, took priority.

\section{The Case}


The case for this study, an eighth-grade science course taught by one teacher in a middle school within the Appalachian region of the Southern United States, was naturally bound by the structure of the school schedule during the time of this study. The general science course was a state-mandated credit that consisted of five major scientific content topics: Structure and Properties of Matter; Chemical Reactions; Growth, Development, and Reproduction of Organisms, Natural Selection; and Human Interactions (citation withheld to maintain anonymity). The teacher in this case taught general eighth grade science to approximately 132 eighth-grade students of varying abilities and academic performances. Her classes consisted of five class periods, each of which included 12-32 students and met for 42 minutes each instructional day.

A total of 83 students were recruited; five were excluded due to absences throughout the study, resulting in a final total of 78 participants. These participants were of 13 to 15 years of age $(M=13.5, S D=0.5)$. The majority of the participants identified as female $(67.7 \%)$, and the remaining participants identified as male (33.3\%). Among the participants, 43 were White (55.1\%), 12 were Asian (15.4\%), 10 were African American or Black (12.8\%), six identified as Other (7.7\%), four were Hispanic/Latino (3.8\%), two were Black and White $(2.6 \%)$, and two were Asian Indian (2.6\%) (see Table 2; the Embedded Units Within the Case section of this manuscript details the group titles within the table). 
Table 2

Demographics of Participants

\begin{tabular}{lrrrr}
\hline & Total & $\begin{array}{c}\text { Assigned } \\
\text { Roles } \\
\text { Makerspace } \\
(n=31)\end{array}$ & $\begin{array}{c}\text { Assigned } \\
\text { Roles } \\
\text { Classroom } \\
(n=27)\end{array}$ & $\begin{array}{c}\text { No Roles } \\
\text { Makerspace } \\
(n=20)\end{array}$ \\
\hline Factor & $\%$ & $\%$ & $\%$ & $\%$ \\
\hline Gender & & & & \\
$\quad$ Male & 33.3 & 25.8 & 40.7 & 35.0 \\
Female & 66.7 & 74.2 & 59.3 & 65.0 \\
Other & 0.0 & 0.0 & 0.0 & 0.0 \\
Age & & & & \\
13 & 48.7 & 61.3 & 48.1 & 30.0 \\
14 & 48.7 & 35.5 & 51.9 & 56.0 \\
15 & 2.6 & 3.2 & 0.0 & 5.0 \\
Race/Ethnicity & & & & \\
Asian & 15.4 & 9.7 & 22.2 & 15.0 \\
Asian Indian & 2.6 & 3.2 & 0.0 & 5.0 \\
Black or African American & 12.8 & 12.9 & 18.5 & 5.0 \\
Black and White & 2.6 & 0.0 & 7.4 & 0.0 \\
Hispanic/Latinx & 3.8 & 3.2 & 0.0 & 10.0 \\
White & 55.1 & 67.7 & 48.1 & 45.0 \\
Other & 7.7 & 3.2 & 3.7 & 20.0 \\
\hline
\end{tabular}

\section{Embedded Units Within the Case}

Though the context of this study was a single case, subunits were embedded within the case (Baxter \& Jack, 2008). In order to explore the impact of maker activity components, community, space, and tools (Litts, 2015), on academic language, there were three subunits. Each subunit consisted of one or two classes. Subunit 1 (Assigned Roles Makerspace) worked in the makerspace to engage in maker activities under role assignments. Subunit 2 (Assigned Roles Classroom) worked in the traditional classroom to engage in maker activities under role assignments. Subunit 3 (No Roles Makerspace) worked in the makerspace to engage in maker activities but without role assignments (see Table 3). The component of community was changed to collaboration, as collaboration is the major element of community as it aims to create a 
community of learners (Litts, 2015; Oxford, 1997). For this study, collaboration consisted of group work under role assignments. Additionally, for this study, space and tools were grouped as separate yet related components since in this case, the availability of tools were dependent on the space. For example, the makerspace offered tools to makers that compared to or differed from the tools in the classroom.

Table 3

Embedded Units within the Case

\begin{tabular}{|c|c|c|c|}
\hline Subunit names & $\begin{array}{c}1 \\
\text { Assigned Roles } \\
\text { Makerspace }\end{array}$ & $\begin{array}{c}\mathbf{2} \\
\text { Assigned Roles } \\
\text { Classroom }\end{array}$ & $\begin{array}{c}\mathbf{3} \\
\text { No Roles } \\
\text { Makerspace }\end{array}$ \\
\hline $\begin{array}{l}\text { Incorporated } \\
\text { components }\end{array}$ & collaboration, space & collaboration & space \\
\hline Description & $\begin{array}{l}\text { Two classes worked } \\
\text { in the makerspace, } \\
\text { engaging in maker } \\
\text { activities } \\
\text { collaboratively by } \\
\text { working in groups of } \\
\text { 3-4 with roles }\end{array}$ & $\begin{array}{l}\text { Two classes } \\
\text { worked in the } \\
\text { classroom, } \\
\text { engaging in maker } \\
\text { activities } \\
\text { collaboratively by } \\
\text { working in groups } \\
\text { of 3-4 with roles }\end{array}$ & $\begin{array}{l}\text { One class worked in the } \\
\text { makerspace, engaging in } \\
\text { maker activities in } \\
\text { groups of 3-4 without } \\
\text { roles }\end{array}$ \\
\hline
\end{tabular}

Subunit 1: Assigned Roles Makerspace. In this subunit, two classes, 31 participants, worked in the makerspace to engage in maker activities under individual role assignments, which served as the collaboration factor. Students collaborated in groups of 3-4 in a space that offered a separate set of tools than that of the traditional classroom. Each member of the group chose a role to support and guide collaboration (a description of these roles can be found in the Intervention section of this manuscript).

Subunit 2: Assigned Roles Classroom. This subunit consisted of two classes, 27 students, who collaborated in the traditional classroom in groups of 3-4. The collaboration piece remained the same as the Assigned Roles Makerspace subunit, as each member adopted an 
assigned role. However, participants remained in the traditional classroom as they utilized classroom resources.

Subunit 3: No Roles Makerspace. Including one class, this subunit of 20 students engaged in maker activities within the makerspace. Participants were directed to work in groups, but without the roles that fostered collaboration.

\section{Learning Environments}

The learning environments consisted of two spaces, the school makerspace and the eightgrade science classroom. The makerspace was a room with various stations along three walls for the following: sewing; jewelry making; vinyl, paper, and fabric cutting; construction (construction bricks, blocks, newspaper connectors, cardboard connectors); consumable and reusable materials, and electronics. Interspersed among stations were a standing desk and three tables for workspace. The remaining wall was lined with a chalkboard, white board for a projector, and low shelves for project and material storage. In the middle of the makerspace were two round, dry-erase top tables with stools. The makerspace adjoined a kitchen that housed three cooking stations, as well as a refrigerator and two microwaves. In the center of the kitchen were two tables with chairs. This space could be used for cooking or for heating, baking, and cooling materials, such as moldable plastic and clay, from the makerspace. At the time of the study, it was commonly used as additional workspace to the makerspace. A door separated these spaces and could be left open or closed. The Assigned Roles Makerspace and No Roles Makerspace subunits worked in the makerspace.

The eighth-grade science classroom was one of the bigger classrooms in the school, including a long, teacher demonstration station at the entrance to the room, as well as four lab stations that lined the back wall and right-side walls. These stations included sinks, and they 
were mostly crowded with class materials and student work. In the center of the room were nine tables, each with four chairs to create group seating for students. On the front wall was a white board with an interactive projector, and on the adjacent left-side wall were two long chalkboards. Toward the back of this wall was a storage closet that was also shared with two other science classrooms. The Assigned Roles Classroom subunit worked in the classroom.

\section{Intervention}

Over the course of five days, each subunit participated in maker activities centered around the same features of academic writing (see Table 4); however, the collaboration and space components within the activities varied according to subunits.

Collaboration. The Assigned Roles Makerspace and Assigned Roles Classroom subunits incorporated role assignments to each group member to facilitate collaboration. Participants worked in groups of characteristics that were correlated to academic achievement: groups of three to four individuals (Bertucci et al., 2010) and heterogenous groups (Crawford et al., 1999). Each member chose a role assignment as a Leader, Facilitator, or Manager. Groups received descriptions and suggested phrases for effectively communicating and carrying out their responsibilities with their group members (see Appendix A). The primary role of the Leader was to make sure that all members had the opportunity to learn (see Table 4). Such duties included encouraging all members to contribute, recording all members' ideas, and redirecting members so that all spend equal time working on a given task. The Facilitator ensured that all members understood the tasks, carrying out responsibilities such as reading directions to the group and seeking out other sources to answer the group's questions. The Manger assured that all members had the necessary resources to complete a task while keeping track of time, familiarizing 
themself with available tools, and overseeing clean-up. Groups of four had two mangers, splitting the tasks of managing time and managing materials.

Table 4

Role Assignments for Groups within Assigned Roles Subunits

\begin{tabular}{|c|c|c|c|}
\hline Role & Leader & Facilitator & Manager \\
\hline Description & $\begin{array}{l}\text { Made sure that all } \\
\text { members had an } \\
\text { opportunity to learn }\end{array}$ & $\begin{array}{l}\text { Made sure that all } \\
\text { members } \\
\text { understood the } \\
\text { task }\end{array}$ & $\begin{array}{c}\text { Made sure that all } \\
\text { members had the } \\
\text { necessary resources for } \\
\text { the task }\end{array}$ \\
\hline Example actions & $\begin{array}{l}\text { Ensured that all } \\
\text { members } \\
\text { contributed } \\
\text { - } \\
\text { Ensured that all } \\
\text { voices were heard } \\
\text { in group } \\
\text { discussions and } \\
\text { decision making } \\
\text { - Recorded ideas } \\
\text { that included all } \\
\text { members' input }\end{array}$ & $\begin{array}{l}\text { Read and } \\
\text { clarified } \\
\text { directions to } \\
\text { the group } \\
\text { - Asked } \\
\text { questions to } \\
\text { other groups or } \\
\text { the teacher } \\
\text { - Used } \\
\text { technology to } \\
\text { research and } \\
\text { reported back } \\
\text { to group }\end{array}$ & $\begin{array}{l}\text { Familiarized oneself } \\
\text { with available tools } \\
\text { in the space } \\
\text { - } \text { Kept track of time } \\
\text { - Ensured that all } \\
\text { materials that were } \\
\text { used among group } \\
\text { members were put } \\
\text { away }\end{array}$ \\
\hline
\end{tabular}

Space. To examine the effect that space and tools may have had on motivation and academic writing development, participants of the Assigned Roles Makerspace subunit and No Roles Makerspace subunit met in the space of the makerspace for all activities and used the available tools. The Assigned Roles Classroom subunit met in the space of the science classroom and used the available classroom tools. The subunits met in their corresponding spaces for all maker activities.

Maker Activities. On the first day of the intervention, participants of all subunits created a physical representation of a vocabulary term related to the previously studied science subjects. Students received one index card with a content vocabulary word, underlined morphemes within 
the words, and a definition of the word on the back. Participants of makerspace subunits utilized makerspace tools, which included items such as pipe cleaners, play dough, construction bricks, paper, clay, cardboard, circuitry kits, and connector straws, to make their creations. Participants of classroom subunit used tools that the teacher had available in the classroom, primarily clay, pipe cleaners, play dough, and construction paper. All of the tools in the classroom were also available in the makerspace, while others, such as construction bricks, fabric, and circuitry kit, were only available in the makerspace. When they finished, participants asked the teacher or researcher to take pictures of their creations. The researcher later uploaded the pictures to websites, separated by periods. The purpose of this activity was to develop a deeper understanding of content vocabulary (see Table 5).

Table 5

Purpose and Rationale of Maker Activities

\begin{tabular}{llll}
\hline \multicolumn{1}{c}{$\begin{array}{c}\text { Maker } \\
\text { Activity }\end{array}$} & \multicolumn{1}{c}{ Description of Activity } & Purpose of the Activity & \multicolumn{1}{c}{ Rationale } \\
\hline $\begin{array}{l}\text { Building } \\
\text { Vocabulary }\end{array}$ & $\begin{array}{l}\text { Each student chose one of } \\
\text { three vocabulary words to } \\
\text { create a representation of a } \\
\text { content vocabulary word }\end{array}$ & $\begin{array}{l}\text { Develop a deep } \\
\text { understanding of content } \\
\text { vocabulary }\end{array}$ & $\begin{array}{l}\text { Content vocabulary is a strong } \\
\text { predictor of information writing } \\
\text { quality (Olinghouse \& Wilson, } \\
\text { 2013) }\end{array}$ \\
& & & $\begin{array}{l}\text { Middle school vocabulary } \\
\text { instruction should include } \\
\text { critical-thinking and problem } \\
\text { solving (Townsend, 2015) }\end{array}$ \\
\hline Unscramble & $\begin{array}{l}\text { Rearrange index cards that } \\
\text { feature a scrambled } \\
\text { paragraph of academic text } \\
\text { that feature content } \\
\text { vocabulary words from the } \\
\text { previous day }\end{array}$ & $\begin{array}{l}\text { Apply strategies to organize } \\
\text { text }\end{array}$ & $\begin{array}{l}\text { This activity will include the } \\
\text { incorporation of organizational } \\
\text { strategies that commonly used } \\
\text { in written academic language } \\
\text { (Fang \& Park, 2019; Uccelli et } \\
\text { al., 2015b) }\end{array}$ \\
& $\begin{array}{l}\text { Revise writing pieces to } \\
\text { include organizational } \\
\text { strategies }\end{array}$ & \\
\hline
\end{tabular}




\begin{tabular}{|c|c|c|c|}
\hline $\begin{array}{l}\text { Vocabulary } \\
\text { Representation } \\
\text { Discussions }\end{array}$ & $\begin{array}{l}\text { View a class website of all } \\
\text { students' vocabulary } \\
\text { representations and discuss } \\
\text { the creations } \\
\text { Revise writing to include } \\
\text { content vocabulary words }\end{array}$ & $\begin{array}{l}\text { Discuss content vocabulary } \\
\text { and broaden vocabulary by } \\
\text { viewing others' work }\end{array}$ & $\begin{array}{l}\text { Students should discuss } \\
\text { academic language and } \\
\text { vocabulary for effective } \\
\text { instruction (Townsend, 2015) }\end{array}$ \\
\hline $\begin{array}{l}\text { Tabletop } \\
\text { Grammar }\end{array}$ & $\begin{array}{l}\text { On a dry erase boards, dry } \\
\text { erase markers to cross out } \\
\text { colloquial phrases within } \\
\text { an academic paragraph and } \\
\text { replace them with } \\
\text { suggested phrases that } \\
\text { establish authority } \\
\text { Revise writing to eliminate } \\
\text { any colloquial phrases and } \\
\text { to include authoritative } \\
\text { indicators }\end{array}$ & $\begin{array}{l}\text { Employ authoritative } \\
\text { indicators }\end{array}$ & $\begin{array}{l}\text { This activity will include } \\
\text { colloquial features based on } \\
\text { those frequently found in } \\
\text { middle school students' } \\
\text { informational writing (Fang \& } \\
\text { Park, 2019) }\end{array}$ \\
\hline $\begin{array}{l}\text { Blocks to } \\
\text { Blocks }\end{array}$ & $\begin{array}{l}\text { In a tabletop game format, } \\
\text { build complex sentences } \\
\text { with blocks } \\
\text { Revise writing to create } \\
\text { more complex sentences }\end{array}$ & Create complex sentences & $\begin{array}{l}\text { Students should practice } \\
\text { combining sentences with } \\
\text { connective markers (Graham \& } \\
\text { Perin, 2007; Truckenmiller \& } \\
\text { Petscher, 2019) }\end{array}$ \\
\hline Word Walls & $\begin{array}{l}\text { Create a poster of an } \\
\text { academic vocabulary } \\
\text { word; posters were hung } \\
\text { for a class-wide gallery } \\
\text { walk } \\
\text { Revise writing to include } \\
\text { academic vocabulary words }\end{array}$ & $\begin{array}{l}\text { Practice academic } \\
\text { vocabulary }\end{array}$ & $\begin{array}{l}\text { Word walls are effective } \\
\text { vocabulary learning strategy } \\
\text { that allow students to explore } \\
\text { meanings of words (Townsend, } \\
2015 \text { ) }\end{array}$ \\
\hline
\end{tabular}

On the second day, students participated in Unscramble by reorganizing a set of index cards, which consisted of segmented paragraphs of written academic language pertaining to the relevant scientific topic, the vestigial nature of the appendix and the significance of evolution. Each index card included a sentence or two, as well as organizational markers so that students could make logical connections between the clauses and put the paragraph in order. Through this activity, students 
interacted with organizational strategies. All subunits were given time to revise their original writing pieces following the Unscramble activity.

On the third day, participants engaged in two makerspace activities to adapt to an interruption caused by a snow day. Students first viewed the Creation Gallery, which was the researcher-made website that contained photographs of other students' creations from the first day of the intervention. Students selected the photographs of the physical structures that they felt best represent the vocabulary words and explained their reasoning. Participants discussed their selection with their peers and revised their original writing pieces focusing on the content vocabulary.

Following that activity, participants completed the Tabletop Grammar activity, during which students received a laminated poster of a written paragraph. The paragraph included nonacademic phrases and elements commonly found in middle school students' informational writing. Such features were colloquial expressions, interrogative or imperative sentences, and discourse fillers (Fang \& Park, 2019). Participants of the Assigned Roles and No Roles makerspace subunits had access to a dry erase markers, since they were tools available in the makerspace. Students used the dry erase markers to annotate the poster by crossing out informal features and, when appropriate, replacing them with provided examples of authoritative indicators used in academic written language (e.g. replace I think that ... with It is possible that ...). When finished, students used a damp cloth to erase their annotations. The Assigned Roles Classroom subunits received both the laminated poster board and an identical 8x11.5 paper with the paragraph, since dry erase markers were not an available tool in the classroom. Therefore, participants used other available resources, such as personal writing utensils or classroom colored pencils to annotate the $8 \times 11.5$ paper. Following the activity, all subunits 
revised their original writing pieces by eliminating colloquial phrases and/or adding more authoritative markers.

Guiding students in exploring complex syntactic structures, on the fourth day participants engaged in Blocks to Blocks, which consisted of color-coded building blocks. Students paired blocks to form complete, complex sentences. Blocks of one color included independent clauses written on them, and blocks of the other color included dependent clauses. In all subunits, participants played a table-top game, during which each player drew four blocks of one color. The first player drew a block of the opposite color, featuring an independent clause, and placed it in the middle of the table. The other players placed one of their blocks, which contained dependent clauses, to complete the sentence, and the first player chose their favorite dependent clause that completed the sentence. The player who placed the preferred block earned a point. This process repeated in turns so that students practiced combining the two types of clauses in order to form complex sentences that mirrored syntactic structures found in academic writing.

On the final day of the intervention, students created and viewed Word Walls by making posters featuring a general vocabulary word (e.g. accumulation, notorious) to explore lexical features through academic vocabulary. Students created a word wall by writing down a thought or drawing a picture that they associate with each word. For example, on the poster board for remnant, a student wrote "small remaining quantity of something," and a groupmate drew a picture of leftover pizza crust. All subunits worked with group members to write a given academic word in the center of the poster board, and each member contributed a drawing, thought, or comment related to the word. However, the Assigned Roles Classroom subunit worked within the classroom, using its tools, while the makerspace subunits worked in the makerspace, utilizing its tools. After finishing their posters, students displayed their work to the 
rest of the class. They then viewed each other's' posters in the form of a "gallery walk" and then revised their original writing pieces to include general academic vocabulary.

\section{Data Collection Procedure}

Prior to the beginning of the unit, participants responded to a prompt to produce a piece of written academic language related to evolution, a topic that had been recently reviewed in class (See Fig. 1). Following the intervention, participants revised their initial writing piece. After the intervention, the participants also completed a survey that included questions that were specifically focused on motivation to complete the maker activities. After students completed their surveys, approximately 17 participants from both groups were selected to participate in an individual interview with the researcher. The researcher also interviewed the teacher about her (teacher's) observations related to students' motivation and writing performance to serve as an additional reality.

Figure 1. Data collection procedures.

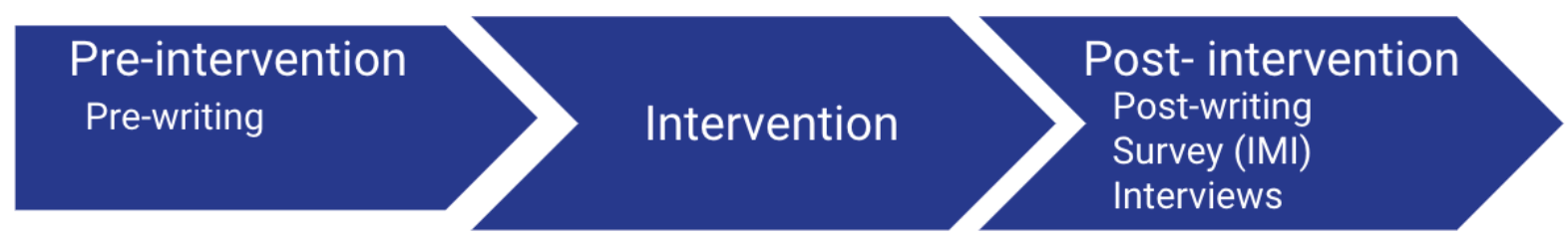

\section{Measures}

Motivation. Student participants completed a 22-item version of the Intrinsic Motivation Inventory (IMI) (Ryan, 1982) as a post-survey. The IMI measured students' perceived choice, perceived competence, pressure/tension, and interest/enjoyment, which are the four major components of motivation (Ryan, 1982). Perceived choice is identified as a positive predictor of intrinsic motivation and refers to how one feels while engaged in a task of choice. Also a positive predictor of intrinsic motivation, perceived competence relates to how effective one feels while 
carrying out a task. Pressure/tension is a negative predictor of intrinsic motivation that corresponds to whether or not one feels coerced to attain a particular outcome of a controlling environmental event (Ryan, 1982). Interest/enjoyment is a positive predictor that is considered to measure the inherent pleasure or interest in a task. The two subscales perceived choice and perceived competence reflect two of the three psychological needs of motivation, according to self-determination theory (Deci et al., 1991): autonomy (perceived choice) and competence (perceived competence). Participants responded to each subscale of the IMI on a 7-point Likert scale (1, indicating not at all true, and 7, indicating very true) (see Appendix B).

In addition to completing survey, 17 student participants were interviewed regarding their motivation to work on maker activities. Additionally, the teacher was interviewed about her observations of student motivation during the intervention. The questions were adapted from interview questions that Litts (2015) utilized in her study on learning in makerspace. Furthermore, the questions were aligned to the four subscales of the IMI, perceived choice, perceived competence, pressure/tension, and interest/enjoyment. Student Interview questions are presented in Appendix C and were administered to students from each subunit, Assigned Roles Makerspace, Assigned Roles Classroom, and No Roles Makerspace. Originally, these participants were to be selected by performance according to their final writing scores, representing students with low, moderate, and high scores. However, due to the urgency of COVID-19-related school closures, the researcher selected any willing participant immediately before the school closed. Additional willing participants were interviewed by videoconference two weeks following the closure. The teacher interview was conducted one week after the closure, also via videoconference. These questions were also aligned to the subscales of the IMI (see Appendix D). 
Academic Language. Participants' pre- and post- writing were assessed by using an academic writing rubric (see Table 6), which was created based on the literature (Fang \& Park, 2019; Schleppegrell, 2001; Snow \& Uccelli, 2009; Uccelli et al., 2015b; Uccelli et al., 2013), outlined in Table 1. The rubric included criteria of lexical choices (content vocabulary, academic vocabulary, and lexically dense terms), organizational strategies, complex syntactic structures, authoritative indicators, and content. In creating the rubric, some features of academic language from Table 1 were combined with others, due to overlapping characteristics. For example, complex morphology (a lexical choice) was combined with content vocabulary (another lexical choice), since vocabulary terms incorporated multi-morphological words. Similarly, expanded noun phrases (a complex syntax feature) was included with lexically dense terms (a lexical choice) because these dense terms could include expanded noun phrases.

Additionally, the interviews were designed to examine participants' perceptions of writing and practice of writing strategies through makerspace activities. The questions were adapted from the interview questions in the makerspace study conducted by Litts (2015). Questions focused on the four subscales of motivation, space, collaboration, and writing (see Appendix C). Questions for the teacher focused on motivation, space, collaboration, and writing, inviting the teacher to share her observations about each variable and their effects on students (see Appendix E).

Table 6

Scientific Writing Rubric 
Criteria

Proficiency Categories and Descriptions
Advanced
Proficient
Emerging
Basic

\section{Lexical}

Features

\begin{tabular}{|c|c|c|c|c|}
\hline $\begin{array}{l}\text { Content } \\
\text { vocabulary } \\
\text { (of complex } \\
\text { morphology) }\end{array}$ & $\begin{array}{l}3+\text { Scientific- } \\
\text { content terms } \\
\text { are used } \\
\text { accurately } \\
8\end{array}$ & $\begin{array}{l}2-3 \text { Scientific- } \\
\text { content terms are } \\
\text { used mostly } \\
\text { accurately } \\
4-6\end{array}$ & $\begin{array}{l}\text { At least one } \\
\text { scientific-content } \\
\text { term is used; some } \\
\text { usage may indicate } \\
\text { misunderstanding } \\
\text { of the term } \\
2\end{array}$ & $\begin{array}{l}\text { Missing science- } \\
\text { content terms } \\
\text { and/or inaccurate } \\
\text { usage of the } \\
\text { terms } \\
0\end{array}$ \\
\hline $\begin{array}{l}\text { Academic } \\
\text { vocabulary }\end{array}$ & $\begin{array}{l}3+\text { General- } \\
\text { academic terms } \\
\text { are used } \\
\text { accurately } \\
8\end{array}$ & $\begin{array}{l}2-3 \text { General- } \\
\text { academic terms } \\
\text { are used mostly } \\
\text { accurately } \\
4-6\end{array}$ & $\begin{array}{l}\text { At least one } \\
\text { general-academic } \\
\text { term is used; some } \\
\text { usage may indicate } \\
\text { misunderstanding } \\
\text { of the term } \\
2\end{array}$ & $\begin{array}{l}\text { Missing general- } \\
\text { academic terms } \\
\text { and/or inaccurate } \\
\text { usage of the } \\
\text { terms } \\
0\end{array}$ \\
\hline $\begin{array}{l}\text { Lexically dense } \\
\text { terms }\end{array}$ & $\begin{array}{l}\text { High proportion } \\
\text { of nouns } \\
\text { through } \\
\text { subordinate } \\
\text { clauses and high } \\
\text { proportion of } \\
\text { modifiers in } \\
\text { noun phrases } \\
8\end{array}$ & $\begin{array}{l}\text { Moderate } \\
\text { proportion of } \\
\text { nouns through } \\
\text { subordinate } \\
\text { clauses and } \\
\text { moderate } \\
\text { proportion of } \\
\text { modifiers in } \\
\text { noun phrases } \\
4-6\end{array}$ & $\begin{array}{l}\text { Moderate } \\
\text { proportion of nouns } \\
\text { through subordinate } \\
\text { clauses OR } \\
\text { moderate } \\
\text { proportion of } \\
\text { modifiers in noun } \\
\text { phrases } \\
2\end{array}$ & $\begin{array}{l}\text { Low proportion } \\
\text { of nouns through } \\
\text { subordinate } \\
\text { clauses and low } \\
\text { proportion of } \\
\text { modifiers in } \\
\text { noun phrases } \\
0\end{array}$ \\
\hline $\begin{array}{l}\text { Complex } \\
\text { Syntax }\end{array}$ & $\begin{array}{l}2+\text { clauses, } \\
\text { such as non- } \\
\text { restrictive } \\
\text { clauses, } \\
\text { nonfinite } \\
\text { clauses, and } \\
\text { appositives, } \\
\text { and/or } \\
\text { nominalization } \\
\text { are used } \\
10\end{array}$ & $\begin{array}{l}2 \text { clauses, such } \\
\text { as non- } \\
\text { restrictive } \\
\text { clauses, } \\
\text { nonfinite } \\
\text { clauses, and } \\
\text { appositives, } \\
\text { and/or } \\
\text { nominalization } \\
\text { are used } \\
6-9\end{array}$ & $\begin{array}{l}\text { At least one } \\
\text { clause, such as } \\
\text { non-restrictive } \\
\text { clauses, nonfinite } \\
\text { clauses, and } \\
\text { appositives, } \\
\text { and/or } \\
\text { nominalization } \\
\text { are used } \\
1-3\end{array}$ & $\begin{array}{l}\text { No clauses, } \\
\text { such as non- } \\
\text { restrictive } \\
\text { clauses, } \\
\text { nonfinite } \\
\text { clauses, and } \\
\text { appositives, nor } \\
\text { nominalization } \\
\text { are used } \\
0\end{array}$ \\
\hline
\end{tabular}




\begin{tabular}{|c|c|c|c|c|}
\hline $\begin{array}{l}\text { Organizational } \\
\text { Strategies }\end{array}$ & $\begin{array}{l}3+\text { Both } \\
\text { explicit and } \\
\text { discourse } \\
\text { markers are } \\
\text { used } \\
\text { throughout the } \\
\text { piece } \\
10\end{array}$ & $\begin{array}{l}2-3 \text { Some } \\
\text { explicit and/or } \\
\text { discourse } \\
\text { markers are } \\
\text { used } \\
6-9\end{array}$ & $\begin{array}{l}\text { At least one } \\
\text { explicit and/or } \\
\text { discourse marker } \\
\text { is used } \\
1-3\end{array}$ & $\begin{array}{l}\text { No explicit nor } \\
\text { discourse } \\
\text { markers are } \\
\text { used } \\
0\end{array}$ \\
\hline $\begin{array}{l}\text { Authoritative } \\
\text { Indicators }\end{array}$ & $\begin{array}{l}3+ \\
\text { Authoritative } \\
\text { indicators are } \\
\text { used to } \\
\text { establish clear } \\
\text { authority } \\
6\end{array}$ & $\begin{array}{l}2-3 \text { Some } \\
\text { authoritative } \\
\text { indicators are } \\
\text { used to } \\
\text { establish } \\
\text { authority } \\
3-5\end{array}$ & $\begin{array}{l}\text { At least one } \\
\text { authoritative } \\
\text { indicator is used, } \\
\text { but authority is } \\
\text { not clear; some } \\
\text { colloquial phrases } \\
\text { may be utilized } \\
1-2\end{array}$ & $\begin{array}{l}\text { No } \\
\text { authoritative } \\
\text { indicators are } \\
\text { used; } \\
\text { colloquial } \\
\text { phrases may be } \\
\text { frequently } \\
\text { utilized } \\
0\end{array}$ \\
\hline Content & $\begin{array}{l}\text { Clear } \\
\text { understanding } \\
\text { of how } \\
\text { evolution } \\
\text { impacts the } \\
\text { role of the } \\
\text { appendix. } \\
\text { Biological } \\
\text { evidence is } \\
\text { present. } \\
35-50\end{array}$ & $\begin{array}{l}\text { Understanding } \\
\text { of how } \\
\text { evolution } \\
\text { impacts the } \\
\text { appendix with } \\
\text { some possible } \\
\text { inaccuracies. } \\
\text { Biological } \\
\text { evidence is } \\
\text { present. } \\
16-35\end{array}$ & $\begin{array}{l}\text { Some } \\
\text { understanding of } \\
\text { how evolution } \\
\text { impacts the } \\
\text { appendix with } \\
\text { possible } \\
\text { inaccuracies. } \\
\text { Biological } \\
\text { evidence is not } \\
\text { present. } \\
1-15\end{array}$ & $\begin{array}{l}\text { Little to no } \\
\text { understanding } \\
\text { of how } \\
\text { evolution } \\
\text { impacts the } \\
\text { role of the } \\
\text { appendix. } \\
\text { Biological } \\
\text { evidence may } \\
\text { not be present. } \\
0\end{array}$ \\
\hline
\end{tabular}

\section{Data Analysis}

Data were collected compared within and across the subunits through cross-case analysis.

Survey Analysis. A one-way analysis of variance (ANOVA) was conducted to analyze the survey (IMI). The two independent variables of this study were collaboration and space. Results were used to determine the two variables' effects on students' motivation to complete an academic writing task across subunits. Further planned comparisons were conducted to determine which variables had an effect on motivation. 
Interview Analysis. The interviews were transcribed verbatim and analyzed through descriptive coding (Saldaña, 2016) to examine students' and the teacher's experience related to academic writing and motivation in relation to space and collaboration.

Analysis of Academic Writing. Students' writing were analyzed through magnitude coding, or method that applies numbers to represent the value of data on a scale (Saldaña, 2016), guided a rubric. Following data transformation, an analysis of covariance (ANCOVA) was conducted to examine the post-writing scores and to determine the independent variables', collaboration and space, effect on students' academic writing performances. Planned comparisons of the post-writing were also performed.

\section{Mixing}

Following quantitative analysis, the interview results were triangulated with to both oneway ANOVAs of the surveys and writing scores. The purpose was to understand why there was or was not a difference between the three subunits' motivation and writing.

\section{Results}

\section{Survey Results}

Descriptive statistics of the survey results are presented in Table 7. To analyze the survey results, a one-way ANOVA was conducted. As Table 8 reveals, results of this test yielded no statistically significant difference among subunits for enjoyment $(F(2,75)=1.501, p=.230, \omega=$ $.08)$, perceived competence $(F(2,75)=0.838, p=.437, \omega=-.04)$, or perceived choice $F(2,75)=$ $0.851, p=.431, \omega=-.04)$. However, the results showed that there was a statistically significant difference for pressure $(F(2,75)=3.180, p=.047, \omega=.16)$. 
Table 7

Descriptive Statistics of Survey Results by Subunit

\begin{tabular}{|c|c|c|c|c|c|c|}
\hline \multirow[b]{2}{*}{ Motivation Subscale $^{\mathrm{a}}$} & \multicolumn{2}{|c|}{$\begin{array}{c}\text { Assigned Roles } \\
\text { Makerspace } \\
\text { (collaboration*space) } \\
(n=31)\end{array}$} & \multicolumn{2}{|c|}{$\begin{array}{c}\text { Assigned Roles } \\
\text { Classroom } \\
\text { (collaboration) } \\
(n=27)\end{array}$} & \multicolumn{2}{|c|}{$\begin{array}{c}\text { No Roles } \\
\text { Makerspace } \\
\text { (space) } \\
(n=20)\end{array}$} \\
\hline & $M$ & $S D$ & $M$ & $S D$ & $\bar{M}$ & $S D$ \\
\hline Enjoyment & 4.59 & 1.29 & 5.08 & 1.48 & 5.14 & 0.95 \\
\hline Perceived competence & 5.01 & 0.98 & 4.94 & 1.12 & 4.63 & 1.10 \\
\hline Perceived choice & 3.59 & 1.23 & 4.02 & 1.60 & 3.58 & 1.44 \\
\hline Pressure $^{b}$ & 2.34 & 0.69 & 2.39 & 1.07 & 2.97 & 1.07 \\
\hline
\end{tabular}

Note. aPossible range of each category: 1-7. bLower score indicates less pressure

Table 8

One-Way ANOVA Results of Survey

\begin{tabular}{lccc}
\hline \multicolumn{1}{c}{ Motivation Subscale } & $F$ & $p$ & $\omega$ \\
\hline Enjoyment & 1.501 & 0.230 & .08 \\
Perceived competence & 0.838 & 0.437 & -.04 \\
Perceived choice & 0.851 & 0.431 & -.04 \\
Pressure & 3.180 & $\mathbf{0 . 0 4 7}$ & 0.16 \\
\hline
\end{tabular}

Note. $p<0.05$

Planned comparisons of the ANOVA revealed that collaboration had a significant effect on students' level of pressure while working on maker activities, as the Assigned Roles Makerspace and Assigned Roles Classroom subunits proved to be significantly different from the No Roles Makerspace subunit for this subscale $(t(75)=-2.359, p=.021, d=-.68 ; t(75)=-1.570$, $p=.038, d=-.62$ ) but not on any of the other subscales (see Table 9). Space did not significantly affect any of the four subscales of motivation. Table 9 presents all planned comparisons results. 
Table 9

Planned Comparisons of One-Way ANOVA Survey Results

\begin{tabular}{|c|c|c|c|c|c|c|}
\hline Subscale & \multicolumn{2}{|c|}{ Contrast Coefficients } & & \multirow[t]{2}{*}{$t$} & \multirow[t]{2}{*}{$p$} & \multirow[t]{2}{*}{$d$} \\
\hline & $\begin{array}{c}\text { Assigned } \\
\text { Roles } \\
\text { Makerspace }\end{array}$ & $\begin{array}{l}\text { Assigned } \\
\text { Roles } \\
\text { Classroom } \\
\end{array}$ & $\begin{array}{c}\text { No Roles } \\
\text { Makerspace }\end{array}$ & & & \\
\hline \multicolumn{7}{|l|}{ Enjoyment } \\
\hline & 1 & -1 & 0 & -1.446 & .152 & -.38 \\
\hline & 1 & 0 & -1 & -1.480 & .143 & -.43 \\
\hline & 0 & 1 & -1 & -0.149 & .882 & -.04 \\
\hline & 2 & -1 & -1 & -1.732 & .087 & -.81 \\
\hline \multicolumn{7}{|l|}{$\begin{array}{l}\text { Perceived } \\
\text { competence }\end{array}$} \\
\hline & 1 & -1 & 0 & 0.258 & .797 & .07 \\
\hline & 1 & 0 & -1 & 1.257 & .213 & .36 \\
\hline & 0 & 1 & -1 & 0.992 & .324 & .29 \\
\hline & 2 & -1 & -1 & 0.922 & .359 & .43 \\
\hline \multicolumn{7}{|l|}{$\begin{array}{l}\text { Perceived } \\
\text { choice }\end{array}$} \\
\hline & 1 & -1 & 0 & -1.165 & .248 & -.31 \\
\hline & 1 & 0 & -1 & 0.033 & .974 & .01 \\
\hline & 0 & 1 & -1 & 1.072 & .287 & .32 \\
\hline & 2 & -1 & -1 & -0.639 & .525 & -.30 \\
\hline \multicolumn{7}{|l|}{ Pressure } \\
\hline & 1 & -1 & 0 & -0.201 & .841 & -.05 \\
\hline & 1 & 0 & -1 & -2.359 & .021 & -.68 \\
\hline & 0 & 1 & -1 & -2.114 & .038 & -.62 \\
\hline & 2 & -1 & -1 & -1.570 & .121 & -.73 \\
\hline
\end{tabular}

Note. $p<0.05$

\section{Pre- and Post-Writing Scores}

Pre- and post-writing pieces were scored using a rubric. The total possible points of an essay were 100. Descriptive statistics of writing can be found in Table 10. A one-way ANCOVA was conducted to determine whether there was a statistically significant difference among the three groups on post-writing, controlling for pre-writing. The analysis result shows that there was no statistically significant difference among the three groups on post-writing. A paired samples $t$ - 
tests show that all three groups' post-writing improved for all features of academic language.

Table 11 presents these results.

Table 10

Descriptive Statistics of Writing Results by Subunit

\begin{tabular}{|c|c|c|c|c|c|c|}
\hline \multirow[b]{2}{*}{ Writing Categories } & \multicolumn{2}{|c|}{$\begin{array}{c}\text { Assigned Roles } \\
\text { Makerspace } \\
\text { (collaboration* space) } \\
(n=31)\end{array}$} & \multicolumn{2}{|c|}{$\begin{array}{l}\text { Assigned Roles } \\
\text { Classroom } \\
\text { (collaboration) } \\
(n=27) \\
\end{array}$} & \multicolumn{2}{|c|}{$\begin{array}{c}\text { No Roles } \\
\text { Makerspace } \\
\text { (space) } \\
(n=20) \\
\end{array}$} \\
\hline & $M$ & $S D$ & $M$ & $S D$ & $M$ & $S D$ \\
\hline \multicolumn{7}{|l|}{ Content vocabulary $^{\mathrm{a}}$} \\
\hline Pre & 1.35 & 1.74 & 1.96 & 2.08 & 0.90 & 1.52 \\
\hline Post & 3.45 & 2.16 & 4.37 & 2.44 & 2.70 & 2.27 \\
\hline \multicolumn{7}{|c|}{ Academic vocabulary ${ }^{b}$} \\
\hline Pre & 0.65 & 1.08 & 1.33 & 2.08 & 0.90 & 1.52 \\
\hline Post & 3.39 & 2.95 & 3.15 & 2.40 & 2.80 & 2.09 \\
\hline \multicolumn{7}{|c|}{ Lexically dense terms ${ }^{c}$} \\
\hline Pre & 4.52 & 2.79 & 4.15 & 3.09 & 4.45 & 2.52 \\
\hline Post & 6.26 & 2.41 & 6.11 & 2.49 & 6.20 & 2.04 \\
\hline \multicolumn{7}{|l|}{ Complex syntax ${ }^{\mathrm{d}}$} \\
\hline Pre & 3.29 & 3.72 & 3.67 & 4.08 & 2.65 & 3.75 \\
\hline Post & 5.65 & 4.19 & 6.04 & 3.77 & 5.55 & 4.11 \\
\hline \multicolumn{7}{|c|}{ Organizational strategies ${ }^{\mathrm{e}}$} \\
\hline Pre & 2.74 & 2.58 & 3.67 & 3.66 & 4.05 & 3.76 \\
\hline Post & 5.74 & 3.28 & 7.59 & 3.21 & 6.85 & 3.12 \\
\hline \multicolumn{7}{|c|}{ Authoritative indicators ${ }^{f}$} \\
\hline Pre & 2.45 & 2.16 & 2.78 & 2.38 & 2.40 & 1.88 \\
\hline Post & 4.26 & 2.56 & 5.04 & 2.01 & 4.30 & 2.20 \\
\hline \multicolumn{7}{|l|}{ Content $^{\mathrm{g}}$} \\
\hline Pre & 20.03 & 14.77 & 22.63 & 17.66 & 19.50 & 18.63 \\
\hline Post & 34.26 & 14.64 & 36.04 & 15.65 & 28.25 & 16.57 \\
\hline \multicolumn{7}{|l|}{ Total $^{\mathrm{h}}$} \\
\hline Pre & 35.03 & 23.70 & 40.19 & 5.59 & 34.85 & 27.30 \\
\hline Post & 63.00 & 26.06 & 68.33 & 5.06 & 56.65 & 24.75 \\
\hline
\end{tabular}

Note. ${ }^{\text {a }}$ Possible range of content vocabulary value: $0-8 .{ }^{b}$ Possible range of academic vocabulary value: $0-8$. c Possible range of lexically dense terms value: $0-8$. ${ }^{d}$ Possible range of complex syntax value: $0-10$. e Possible range of organizational strategies value: $0-10 .{ }^{f}$ Possible range of authoritative indicators value: $0-6$. g Possible range of content value: $0-50$. ${ }^{\mathrm{h}}$ Possible range of total value: $0-100$ 
Table 11

Paired-Samples t-Test Results of Pre-and Post-Writing by Subunit

\begin{tabular}{|c|c|c|c|c|c|c|c|c|c|}
\hline \multirow[b]{2}{*}{ Writing Categories } & \multicolumn{3}{|c|}{$\begin{array}{c}\text { Assigned Roles } \\
\text { Makerspace } \\
\text { (collaboration*space) } \\
(\mathrm{n}=31)\end{array}$} & \multicolumn{3}{|c|}{$\begin{array}{c}\text { Assigned Roles } \\
\text { Classroom } \\
\text { (collaboration) } \\
(n=27)\end{array}$} & \multicolumn{3}{|c|}{$\begin{array}{c}\text { No Roles } \\
\text { Makerspace } \\
(\text { space }) \\
(n=20)\end{array}$} \\
\hline & $t$ & $p$ & $d$ & $\mathrm{t}$ & $p$ & $\bar{d}$ & $t$ & $p$ & $\bar{d}$ \\
\hline Content vocabulary & -6.641 & $<.001$ & -1.19 & -5.583 & $<.001$ & -1.07 & -3.943 & .001 & -.88 \\
\hline Academic vocabulary & -5.799 & $<.001$ & -1.04 & -4.542 & $<.001$ & -.87 & -5.146 & $<.001$ & -1.15 \\
\hline Lexically dense terms & -5.314 & $<.001$ & -.95 & -4.580 & $<.001$ & -.88 & -4.027 & .001 & -.90 \\
\hline Complex syntax & -4.587 & $<.001$ & -.82 & -3.712 & .001 & -.71 & -2.470 & .023 & -.55 \\
\hline Organizational strategies & -5.547 & $<.001$ & -1.00 & -7.113 & $<.001$ & -1.37 & -3.704 & .002 & -.83 \\
\hline Authoritative indicators & -4.365 & $<.001$ & -.77 & -4.836 & $<.001$ & -.93 & -5.871 & $<.001$ & -1.31 \\
\hline Content & -5.870 & $<.001$ & -1.05 & -4.650 & $<.001$ & -.90 & -5.280 & $<.001$ & -1.18 \\
\hline Total & -8.602 & $<.001$ & -1.55 & -7.577 & $<.001$ & -1.46 & -7.939 & $<.001$ & -1.78 \\
\hline
\end{tabular}

Note. $p<0.05$

\section{Student Interview Results}

The analysis of the interview data suggest that students enjoyed working in collaboration, despite having roles or not. Students attributed this enjoyment to working toward a shared goal and to receiving peer support during maker activities and knowledge construction. Social dynamics also seemed to affect their enjoyment. However, working in groups did present challenges related to determining a group consensus and unequal contributions among group members. Additionally, working in groups helped students improve their writing. When facing challenges, assigned roles appeared to affect students' pressure to complete maker activities. The No Roles Makerspace subunit was more likely to take issue with other group mates staying on task, whereas the Assigned Roles subunits reported more challenges due to dissension when making group decisions. Space affected students' enjoyment of the maker activities due to movement and resources. As students engaged in maker activities, students developed academic 
language features as well as content knowledge related to the science curriculum. Finally, students of all subunits noted that their writing improved following the intervention.

The interview results revealed that students enjoyed working in groups, but also experienced challenges during collaboration. Most students stated that they enjoyed working in groups, especially when they worked toward a goal, helped one another, and experienced balanced social dynamics. Students liked working collectively toward a goal. Many students noted how they appreciated how their group mates "worked together" while undertaking the maker activities. One student noted, "It was nice because we all worked together. It's not like one person did all of it...we worked really well together."

Along with collective effort, students experienced peer support in completing maker activities and constructing knowledge. A participant recalled how she felt frustrated when she was trying to decide how to create her vocabulary representation. "I was getting frustrated, but then my group helped me decide on what I wanted to do," she noted, "and other classmates [helped]." Additional students reflected on how their group mates helped them to carry out the maker activities. "My group was helpful to me as much as I was helpful to them," one student explained. In addition to receiving peer support to complete activities, students also reported that felt that peers supported in knowledge construction. According to the interviewees, engaging in discussion contributed to this experience. As one student mentioned, "[We] had to discuss and talk about [the activities] ...That was nice—-talking to [my] group and figuring it out what worked and what didn't." Another student said that working with his group affected his comprehension through peer discussion. "It made me understand [the content] better than having to do it by myself," he added. 
As students expounded on working in groups, many highlighted the influence of social dynamics and how that influenced their enjoyment working in a group setting. Several students commented on the importance of balance among the dynamics. As one student described her group, "We could joke around and stuff, but we also knew when it was time to actually get work done and actually work together and stuff. And that's good to have a bit of balance when you're doing group activities." Some students mentioned that they appreciated a sense of "friendl[iness]" among their group mates, as well as a sense of fun. Though students had fun, they also acknowledged the importance of cooperation. Participants seemed to value social characteristics of their groups when coupled with equal contribution.

Conversely, the lack of such balance presented a challenge. For example, one student stated: "I don't like working with the groups cause not everybody does what they're supposed to do. And we'll all fall back and make everybody's grades suffer. So I like working independently." When asked whether that was the case in the makerspace, she said yes. When later asked to recall a challenge while working in the makerspace, the student related back to her group experience. “[My groupmate] did most of it, but I just didn't understand so I couldn't learn if I couldn't understand." Others echoed similar experiences, recounting how one of their group mates "kept leaving" the group or was frequently off task. However, this imbalance only seemed to affect these participants' sense of pressure and not their sense of enjoyment.

All interviewees agreed that working in a group improved their writing. Following each maker activity, the teacher and researcher prompted students to incorporate into their writing the academic language feature of focus that day. On their own fruition, many students switched papers or read their work aloud to their groups in order to peer revise. The majority of interviewees explained how peer editing provided a variety of ideas, suggestions, or opinions in 
regard to writing. From "bouncing ideas off each other" to "finding things" that the author hadn't noticed, students claimed that this process resulted in better writing, even if they did not always agree with suggested changes. As one student noted:

We could merge our ideas and then our opinions. So I think it maybe helped me for the benefit of the better. Other times where it didn't cause I was like, 'Great. But I feel like this is more right'...but I think that it helped me a lot more.

Students in the Assigned Roles subunits reported that assigned roles helped group members contribute to the project and recount challenges related to consensus. A participant claimed that since each student had a role, his group mates knew what they were supposed to do in order to achieve a common goal. Another student noted how the assigned roles led to a natural integration of shared effort: "I found that by the end, we were all just doing it all together a little. We forgot our roles, and we'd just read the instructions together and all work together," Students in the Assigned Roles subunits, in which roles were fulfilled, were more likely to recount a challenge related to developing a group consensus. Some students recalled that "it was hard to agree on something" or to "work together in one concept." While several students described a shared challenge while they worked on the maker activities, many found solutions with their peers, as exemplified by one student's statement, "We had to come together and eventually we came together and make something work." One student credited her group's ability to work together to their respective roles. "I remember every day what I had to do and what everybody else had to do. So it was good that they kept on task too," she said. Though most students in these subunits reported a balance of contribution, some students still experienced an imbalance. One student in the Assigned Roles Makerspace subunit said that one of her group members completed most of the work, and another student in the Assigned Roles Classroom subunit 
reported that one group member kept leaving the group. Aside from these occurrences, the majority of students in the Assigned Roles subunits experienced pressure when their work effort or ideas differed from that of their peers.

On the other hand, students in the No Roles Makerspace subunit were more likely to report a challenge in collaboration due to a lack of focus on the task or an imbalance in group cooperation. Students reported that their group members were "off task a little bit" or would leave the group and was not presented when needed. One student pointed out that another group member "did more than the other people" and she felt that "other people weren't getting really a chance" to participate in the activity. Other students in this subunit reported a distraction by conversation in his group or when immediate workspace was shared with another group. In summary, without the presence of roles, students in the No Roles Makerspace subunit noted more instances of distraction and work imbalance.

On the whole, students from the Assigned Roles Makerspace and No Roles Makerspace subunits said that the enjoyed working in the makerspace and directly related their enjoyment to the physical space and the creativity that the space afforded. One student noted how the makerspace is different than the "traditional classroom environment." He added, "You're not staying in a desk. You're not stationary." Other students said that they appreciated the aspect of being able to "move" or "walk" around the space. According to some students, movement contributed to collaboration. "You're moving around and working with everyone," said a student. Some students commented on the resources within the space and the creativity that the materials afforded. For example, one student stated that she was able to be more creative in the makerspace because there were more "arts and crafts stuff" available to her. 
Interviewees revealed that during the maker activities they developed skills in applying some of the academic language features. As one student summarized, he learned about how to write_ " "not just the sciencey stuff, but English too." Participants claimed that they learned how to make their sentences "flow" by omitting colloquialisms, reorganizing their writing, and creating more complex sentences. "[Doing the blocks-to-blocks activity] helped me to understand compound sentences rather than if I had just read an article," commented a student.

While the focus of the intervention was on academic language features, many interviewees noted that they learned course content by carrying out the maker activities. Most of these participants said that they learned about the appendix or how humans have evolved. During the interview, many students applied this knowledge by explaining to the researcher how evolution affected the human appendix. In relation to this topic, several students said that they learned new vocabulary, in regard to semantics as opposed to the utilization of the words as a language strategy. One student demonstrated a combination of acquired vocabulary and application when he said, "I learned about how vestigial organs... were once probably useful to our ancestors and now not to us anymore and how we changed over time."

Almost all students claimed that their final drafts were better than their first drafts and credited this to either learning more content or learning about language strategies. Some students even acknowledged how the acquisition of both content knowledge and language strategies resulted in enhanced writing. In describing her final draft, an interviewee said, "I had a lot more knowledge, and [my draft] was more well-written and developed." Another student explained "[My final draft] was structured a lot better...it was more enjoyable to write the final draft than the rough draft because I knew more." 
Overall, acquired content knowledge or academic language strategies—or a combination of both—led to students' increased confidence in their final writing product.

\section{Teacher Interview Data}

The teacher interview revealed that students enjoyed working in groups, regardless of roles, though students in the Assigned Roles Makerspace and Assigned Roles Classroom subunits did enjoy having roles. The teacher noted that students particularly enjoyed wearing lanyards, which held tags that displayed each students' role and its responsibilities. The teacher noted that some students in the Assigned Roles Makerspace subunit needed redirection even though they had roles, whereas the majority of students in the No Roles Makerspace subunit without roles, were able to work more autonomously in their groups. Even without jobs, she said, the No Roles Makerspace displayed more confidence than the Assigned Roles Classroom subunit when working in their groups, as the No Roles Makerspace students worked more autonomously and asked the teacher for less guidance. She attributed this to the class make-up of students. Nevertheless, she also noticed how students in all subunits engaged in peer review when editing their papers after each maker activity.

In terms of space, the teacher interview data indicated that students were able to effectively carry out the maker activities whether or not they worked in the makerspace. This had to do more with the available resources within the space. "The materials that I had for [the students] in the classroom [were] still enough that [students] could do the actual activities...they were still able to do the same things," she explained. Nor did space seem to influence students' ability to collaborate. However, she believed that the space of the makerspace provided a challenge for both the students and teacher. "I honestly think it was more organized in the classroom because of the way I have my tables laid out...I think it threw [students] off in the 
makerspace [because] they could either stand or sit on the floor," she claimed. Because makerspace of this particular case spans across two rooms, she observed that it was difficult to "constantly...stand in the door and back and forth" to supervise. Even so, the teacher did find that students were more comfortable collaborating in the makerspace because it provided a type of "coffee shop" setting in which students were more comfortable.

\section{Discussion}

This study investigated the effects of collaboration, or having role assignments, and space on middle school students' motivation and academic writing quality through makerspace activities. The analysis of quantitative data shows that having role assignments significantly lowered students' sense of pressure, but no other subscales of motivation. Role assignments did not affect academic writing quality. Space had no apparent effect on neither motivation nor quality. There were no statistically significant differences among the three groups in post-writing scores. All subunits' writing scores increased following the intervention.

The analysis of interviews indicates that across the subunits, students enjoyed working with peers to attain a common goal and receiving peer support in the process. Their enjoyment was influenced by groups' social dynamics. All students reported facing challenges in their groups, which affected their sense of pressure; however, role assignments seemed to determine the type of challenges that students encountered. Students who did not have assigned roles reported challenges related to group mates being distracted or not completing group tasks. Students of the Assigned Roles subunits, on the other hand, reported less pressure. When they did face challenges in collaboration, they were more likely to experience difficulties in making group decisions. A possible reason for this result may be that all, or the majority of, students in assigned roles subunits contributed to the project. These results suggest that students with 
assigned roles focused more on creating a learning community as opposed to simply completing a task, effectively achieving collaborative learning (Oxford, 1997).

Operating under group roles helped to decrease students' pressure as they worked on maker activities. Interview data suggest that group roles helped students to focus on a task that resulted in collaborative discussion, which may have resulted in less off-task behavior. These findings mirror those of prior research on the efficacy of collaborative learning with group roles (Moore et al., 2019). Especially within STEM, the present study also supports prior research, which indicates that peer collaboration with group roles can lead to increased motivation, which other authors have defined as taking an active role one's responsibility with an element of interest (Taylor \& Baek, 2018).

This study also adds to previous research that suggests role assignments can significantly decrease student stress while working in groups (Sofroniou \& Poutos, 2016). Though the current study did not measure stress, the pressure subscale of the IMI (Ryan, 1982) utilized terms such as "nervousness," "anxiety," and "tensions," which could be applied to stress. Students with group roles may have felt such alleviation of pressure because their energy was more devoted to a specific task, which resulted in more interaction with their peers; subsequently, they were able to provide more help and support, which students valued. As a result, they were less likely to engage in a distraction, a behavior that students particularly did not enjoy from their group mates. Previous research on makerspaces as a learning environment found that students experience a variety of stress, depending on individual skills and expertise (Jalal \& Anis, 2020). This study contributes to the literature by suggesting that a possible strategy to alleviate students' stress during maker activities is to assign individual roles to students. 
There was no statistically significant difference among the groups in post-writing scores, which shows that assigned roles did not contribute to the improvement of students' writing. There are two possible reasons. One reason may be that students adhered to their roles strictly during the hands-on segment of the maker activities. When students finished the interactive portion, they revised their writing and may not have applied their roles during this segment of the activity. As an example, the facilitator of a group was to read the directions of each maker activity, which included revising their written work. However, the instructions for the hands-on portion of the activity varied widely from day-to-day, while the writing instructions remained relatively the same (e.g. "When you're done...revise your [writing] to include [respective academic language feature]"). The facilitator may have stopped reading the writing instructions due to their predictability. Another reason the roles may not have carried over to student writing was due to the wording of the instructions. Most days, the written instructions read "When you're done, revise..." The intent of the instructions was to guide students when they were finished the hands-on segment, but students may have interpreted it as the entire group activity being finished. Consequently, they ceased carrying out their roles' responsibilities during the writing segment. When the groups edited peers' writing at the end of each day, they did not fulfill their responsibilities.

Second, although only students in the Assigned Roles Makerspace and Assigned Roles Classroom subunits had roles, it is possible that students in the No Roles Makerspace subunit were already practiced at collaborative work, so they unwittingly assumed cooperative roles. Teacher interview data show that students from all subunits had prior experience working in groups within the science classroom. In past group activities, the teacher would not assign distinct roles with physical role cards, but she would tell groups to designate someone in the 
group to carry out certain responsibilities, such as cleaning up. As a result, students in No Roles Classroom subunit may have drawn from prior experience and assumed collaborative roles.

When considering the component of space, it is possible that this factor had no effect on students' motivation or writing due to the original layout of the science classroom within the case. Interview results revealed that students enjoyed working in the makerspace because of their ability to walk around and the physical layout, which allowed for collaboration. However, the students who worked in the classroom had similar opportunities to walk around and work with peers. Like the makerspace, the science classroom housed tables that were conducive to working in groups. Along similar lines, the science classroom offered resources comparable to that of the makerspace. Although the makerspace stored a wider variety of resources for creating, for example, newspaper connectors, cardboard toolkits, and electronic kits, students in the makerspace subunits generally chose to work with materials that students in the classroom also used. Such resources included markers, pipe cleaners, clay, and play dough. Results may have differed if students in the Assigned Roles Classroom subunit had worked in a classroom with a more traditional layout with rows of individual desks instead of tables and with less materials that encouraged hands-on activity, which students revealed that they enjoyed. Additionally, results may have varied if students had opted to use the higher technologies of the makerspace. Perhaps students chose low-tech resources because they were not familiar with devices such as the Makey Makeys or balsa wood cutter.

All subunits' writing quality significantly improved, in terms of both academic language and content. These findings indicate that, the maker activities had a positive effect on students' academic writing and content knowledge. One possible explanation for enhanced academic language may be that, regardless of role assignment or working space, all students were given 
the opportunity to apply maker activity objectives to their writing. They were able to focus their attention to individual features of academic language or specific acquired knowledge instead of the overarching task of improving their writing. For example, all students interacted with organizational strategies during a maker activity. When they were given time to revise their writing at the end of the activity, students may have solely concentrated on applying organizational strategies. Integrating time for focused revisions during each maker activity may have had a positive impact on students' academic writing.

Students' writing also improved due to their increased content knowledge. This may have improved due of students' exposure to content that was integrated into the maker activities. Though content knowledge was not a variable of focus in this study, the results imply that students learned content knowledge related to the human appendix and evolution. This may be due to the fact that the maker activities were themed around the content. For example, when students reorganized the paragraphs of an article to practice organizational strategies, they read about the latest research about the human appendix. Or when they practiced complex syntax by constructing blocks, they read clauses about vestigial organs. An unanticipated result was an increase of content knowledge in students' writing. Prior research shows that maker activities increase student content knowledge (Doran et al., 2012), and the present study's results suggest similar findings in that students' content knowledge increased after engaging in maker activities. As Tham (2019) suggests, applying maker activities are effective pedagogical practice to teach writing.

This study also demonstrates that students can acquire content knowledge through maker activities, affirming the theory of constructionism. Learning transpired when students interacted with tangible objects that promoted examination and discussion (Papert, 1993). Students 
manipulated materials to create representations of vocabulary words. They physically moved segments of an academic article. They combined building blocks to create complex syntax. They annotated and created posters to discuss the meaning of academic terms and colloquial discourse. Through this process of personal interaction with external artifacts, students learned science content and academic language strategies by making. These findings are significant because outside the area of programming, few studies address makerspaces and the construction of content knowledge that relate to curricula learning standards (Papavlasopoulou et al., 2017). As the present studied explored the impact of makerspace activities related to NGSS and English Language Arts standards, this finding may help to fill the gap in makerspace literature, which fails to address the role of makerspaces in direct relation to standards-based curricula in K-12 education.

Finally, a considerable finding of this study is that all subunits enjoyed the maker activities. This results aligns with prior research that suggests STEM education can enhance student motivation in terms of interest (Rosenzweig \& Wigfield, 2016), particularly in science intrinsic motivation (LaForce et al., 2017). Working specifically in a makerspace can lead to higher levels of interest among students (Vongkulluksn et al., 2018), though the present study suggests that levels of interest or enjoyment can occur outside of the space of a makerspace, as long as students engage in makerspace-like activities. This enjoyment may have resulted due to the inherent collaborative nature of maker activities (Litts, 2015), since the interview data show that students liked working collaboratively toward a goal or helping one another in groups.

\section{Limitations}

There were notable limitations of this study. First, due to the small sample size, the results of this study are not widely generalizable, which is often a characteristic of case studies 
(Merriam, 2009). Also a feature of case studies, the bounded context system, or case (Merriam, 2009), presents its own particular challenges that may not be present in other contexts. For example, the makerspace in this setting primarily housed low technologies. Makerspaces in other school settings may offer higher technologies, which could result in implications not found in this study. The findings of this case study cannot be applied universally; however, as Stake (1995) suggests, the reader may reconstruct the contents of this study to apply them to other relevant contexts.

Furthermore, researcher bias may be present in this study. For example, bias during data analysis may have taken effect since the pre-writing samples were handwritten, and the postwriting scores were typed. Following the intervention, the teacher requested that all students submit their final writing pieces through a computer. During the analysis of pre- and post-writing samples, the researcher consequently knew which samples were composed before and after the intervention.

Finally, the final steps of data collection were periodically disrupted due to COVID-19related school closures. Some of the student interviews were conducted with limited time, not allowing as much opportunity to gather richer data. Because of the sudden closures, the researcher interviewed any willing participant, instead of selecting interviewees based on preand post-writing scores, as originally planned. As a result, subunits were disproportionately represented. Interviews that were not conducted on-site were held over videoconference web applications, which could have changed the dynamic of the interviews.

\section{Implications}

Implications for Practice. This study offers implications for utilizing makerspaces in K12 education settings. First, though makerspaces have shown to improve student self-efficacy 
(Schlegel et al., 2019; Vongkulluksn et al., 2018), this study suggests that the physical space of a makerspace may not be necessary. Teachers can still engage in maker pedagogy from their classrooms. However, they may want to consider maintaining similar fundamental elements of a makerspace, such as seating that encourages collaboration and movement. To accommodate teachers who may not have access to a variety of materials, school leaders may want to consider investing in more cost-efficient maker programs such as maker carts, which could store materials and be transported directly to classrooms.

As the results indicate, students may learn content while working on maker activities that are directly related to curriculum learning standards. Students who engage in maker activities may construct knowledge base on course content. As well as providing physical aspects similar to makerspaces, teachers, in their classrooms, may also want to develop pedagogy based in maker education. By implementing lessons that include collaborative learning and engagement in with external artifacts, teachers could foster maker education without leaving the classroom. A formal, designated makerspace may not be an essential to carry out such pedagogy.

Finally, educators who integrate maker activities may want to consider applying group work with individual role assignments, since the present findings suggest that students will devote more time to engaging in on-task behaviors with their group rather than to an external distraction. Though this study did not implement role rotation, other studies in STEM education suggest that role rotation among group member may be more effective in a collaborative setting (Taylor \& Baek, 2018; Zhong \& Wang, 2019). Educators who practice maker education may want to consider this practice, as well.

Implications for Future Research. Future research that explores makerspaces in a K-12 education setting may want to further investigate factors that affect collaboration. The present 
study implemented role assignments to achieve collaborative learning. However, a myriad of strategies may also promote collaboration in makerspaces. For example, group contracts and ratings of peers' contributions are recommended strategies to facilitate collaborative learning (Chang \& Brickman, 2018); they may also be effective in a makerspace. If role assignment is utilized, researchers may want to consider routinely rotating roles so that all group members have the opportunity to demonstrate various collaborative learning skills (Taylor \& Beck, 2018; Zhong \& Wang, 2019). Going forward, studies that focus on collaboration in makerspaces may want to integrate all or some of these strategies.

Additional studies on makerspaces in formal, K12 learning settings may also want to include a control group in which students interact in a more traditional classroom with less space for collaboration and less resources for students to interact with tangible objects. Possible findings that correlate space to student motivation or performance may imply that makerspaces are worth investments in schools, or they may further support the results of this study, suggesting that makerspaces are not necessary investments. Future studies could also involve a control group of students who are not as experienced in collaborative learning. Results may indicate that cooperative strategies may be even more effective in maker activities than the present study implies.

Conversely, in terms of an experimental group, future research may want to further explore the factor of space. Though the makerspace of this case study housed some devices, such as a Cricut, sewing machine, Makey Makeys, and circuitry kits, it provided primarily low technologies, such as construction bricks, clay, makers, paper, glue guns, and fabric. Students did not opt to use the higher technology, perhaps due to their lack of experience in using such tools. Studies in the future may want to include an experimental group in which students actually 
utilize higher technologies and directly investigate the impact on student learning that is directly related to curriculum content. While many studies have focused on makerspaces with high technology (e.g., Kafai et al., 2014; Lin et al., 2018; Litts, 2015), few of them have measured the impact on student performance of content learning outcomes (Papavlasopoulou et al., 2017). 


\section{References}

Balgopal, M., \& Wallace, A. (2013). Writing-to-learn, writing-to-communicate, and scientific literacy. The American Biology Teacher, 75(3), 170-175. https://doi.org/10.1525/abt.2013.75.3.5

Bandura, A. (1986). Social foundations of thought and action: A social cognitive theory. Prentice-Hall.

Baxter, P., \& Jack, S. (2008). Qualitative case study methodology: Study design and implementation for novice researchers. The Qualitative Report, 13(4), 544-559.

Benjes-Small, C., Bellamy, L. M., Resor-Whicker, J., \& Vassady, L. (2017). Charting a course for successful academic library makerspaces. At the Helm: Leading Transformation, 428436.

Bers, M. U., Strawhacker, A., \& Vizner, M. (2018). The design of early childhood makerspaces to support positive technological development: Two case studies. Library Hi Tech, 36(1), 75-96. https://doi.org/10.1108/LHT-06-2017-0112

Bertucci, A., Conte, S., Johnson, D. W., \& Johnson, R. T. (2010). The impact of size of cooperative group on achievement, social support, and self-esteem. The Journal of General Psychology, 137(3), 256-272. https://doi.org/10.1080/00221309.2010.484448

Bruning, H., \& Kauffman, D. F. (2015). Self-efficacy beliefs and motivation in writing development. In Handbook of writing research, second edition (pp. 160-173). Guilford Publications.

Bruning, R., Dempsey, M., Kauffman, D. F., McKim, C., \& Zumbrunn, S. (2013). Examining dimensions of self-efficacy for writing. Journal of Educational Psychology, 105(1), 2538. https://doi.org/10.1037/a0029692 
Burke, Q., \& Kafai, Y. B. (2012). The writers' workshop for youth programmers: Digital storytelling with scratch in middle school classrooms. Proceedings of The 43rd ACM Technical Symposium on Computer Science Education, 433-438. https://doi.org/10.1145/2157136.2157264

Chai, H., \& Welz, V. L. (2018). Creating vocabularians: Sharing strategies to support social studies vocabulary instruction. Ohio Social Studies Review, 55(1), 43-53.

Chang, Y., \& Brickman, P. (2018). When group work Doesn't work: Insights from students. CBE—Life Sciences Education, 17(3), ar52. https://doi.org/10.1187/cbe.17-09-0199

Cleary, T. J., \& Kitsantas, A. (2017). Motivation and self-regulated learning influences on middle school mathematics achievement. School Psychology Review, 46(1), 88-107. https://doi.org/10.17105/SPR46-1.88-107

Crawford, B. A., Krajcik, J. S., \& Marx, R. W. (1999). Elements of a community of learners in a middle school science classroom. Science Education, 83(6), 701-723. https://doi.org/10.1002/(SICI)1098-237X(199911)83:6<701::AID-SCE4>3.0.CO;2-2

DCI arrangements of the Next Generation Science Standards. (2017). Achieve, Inc. https://www.nextgenscience.org/overview-dci

Deci, E. L., Vallerand, R. J., Pelletier, L. G., \& Ryan, R. M. (1991). Motivation and education: The self-determination perspective. Educational Psychologist, $26(3$ \& 4), 325-346.

Doran K., Boyce A., Finkelstein S., \& Barnes T. Outreach for improved student performance: A game design and development curriculum. Annual Conference on Innovation and Technology in Computer Science Education, ITiCSE, 209-214. WorldCat.org. https://doi.org/10.1145/2325296.2325348 
Fang, Z., \& Park, J. (2019). Adolescents' use of academic language in informational writing. Reading and Writing. https://doi.org/10.1007/s11145-019-09937-8

Fields, D. A., Kafai, Y. B., Strommer, A., Wolf, E., \& Seiner, B. (2014). Interactive storytelling for promoting creative expression in media and coding in youth online collaboratives in Scratch. Proceedings of Constructionism, 19-23.

Freeman, A., Adams Becker, S., Cummins, M., \& Hall Giesinger, C. (2017). NMC/CoSN Horizon Report: 2017 K-12 Edition. The New Media Consortium.

Galaleldin, M., Bouchard, F., Anis, H., \& Lague, C. (2017). The impact of makerspaces on engineering education. Proceedings of the Canadian Engineering Education Association (CEEA). https://doi.org/10.24908/pceea.v0i0.6481

Gallagher, M. A., \& Anderson, B. E. (2016). Get all “jazzed up” for vocabulary instruction: Strategies that engage. The Reading Teacher, 70(3), 273-282. https://doi.org/10.1002/trtr.1498

Garneli, B., Giannakos, M. N., Chorianopoulos, K., \& Jaccheri, L. (2013). Learning by playing and learning by making. International Conference on Serious Games Development and Applications, 76-85.

Gere, A. R., Limlamai, N., Wilson, E., MacDougall Saylor, K., \& Pugh, R. (2019). Writing and conceptual learning in science: An analysis of assignments. Written Communication, 36(1), 99-135. https://doi.org/10.1177/0741088318804820

Graham, S., \& Perin, D. (2007). A meta-analysis of writing instruction for adolescent students. Journal of Educational Psychology, 99(3), 445-476. https://doi.org/10.1037/00220663.99.3.445 
Guzey, S. S., Ring-Whalen, E. A., Harwell, M., \& Peralta, Y. (2019). Life STEM: A case study of life science learning through engineering design. International Journal of Science and Mathematics Education, 17(1), 23-42. https://doi.org/10.1007/s10763-017-9860-0

Hartnett, E. J. (2016, October). Public libraries online. Public Library Association, 55(5). http://publiclibrariesonline.org/issue/volume-55-no-5/

Hsu, Y.-C., Baldwin, S., \& Ching, Y.-H. (2017). Learning through making and maker education. TechTrends, 61(6), 589-594. https://doi.org/10.1007/s11528-017-0172-6

Jalal, M., \& Anis, H. (2020). The integration of a maker program into engineering design courses. International Journal of Engineering Education, 36(4), 1253-1270.

Jeffery, J. V., \& Wilcox, K. (2014). 'How do I do it if I don't like writing?': Adolescents' stances toward writing across disciplines. Reading and Writing, 27(6), 1095-1117. https://doi.org/10.1007/s11145-013-9493-9

Johnson, D. W., Johnson, R. T., \& E. J. Holubec. (1994). What is cooperative learning? In The New Circles of Learning: Cooperation in the Classroom (pp. 1-12). Association for Supervision and Curriculum Development.

Johnson, M. D., Acevedo, A., \& Mercado, L. (2016). Vocabulary knowledge and vocabulary use in second language writing. TESOL Journal, 7(3), 700-715. https://doi.org/10.1002/tesj.238

Kafai, Y., Fields, D., \& Searle, K. (2014). Electronic textiles as disruptive designs: Supporting and challenging maker activities in schools. Harvard Educational Review, 84(4), 532556. https://doi.org/10.17763/haer.84.4.46m7372370214783 
Kindermann, T. A. (2016). Peer group influences on students' academic motivation. In K. R. Wentzel \& G. B. Ramani (Eds.), Handbook of Social Influences in School Contexts: Social-Emotional, Motivation, and Cognitive Outcomes (p. 17). Routledge.

Klassen, R. (2002). Writing in early adolescence: A review of the role of self-efficacy-beliefs. Educational Psychology Review, 14(2), 173-203.

Kobayashi, M., Zappa-Hollman, S., \& Duff, P. A. (2017). Academic discourse socialization. In P. A. Duff \& S. May (Eds.), Language Socialization (pp. 1-17). Springer International Publishing. https://doi.org/10.1007/978-3-319-02327-4_18-1

LaForce, M., Noble, E., \& Blackwell, C. (2017). Problem-Based Learning (PBL) and student interest in STEM careers: The roles of motivation and ability beliefs. Education Sciences, 7(4), 92. https://doi.org/10.3390/educsci7040092

Lin, K.-Y., Hsiao, H.-S., Chang, Y.-S., Chien, Y.-H., \& Wu, Y.-T. (2018). The effectiveness of using 3D printing technology in STEM project-based learning activities. Eurasia Journal of Mathematics, Science and Technology Education, 14(12). https://doi.org/10.29333/ejmste/97189

Litts, B. K. (2015). Making learning: Makerspaces as learning environments (Doctoral Dissertation, University of Wisconsin-Madison ). Retrieved from https://www.informalscience.org/sites/default/files/Litts_2015_Dissertation_Published.pd f

McKeown, M. G., Crosson, A. C., Moore, D. W., \& Beck, I. L. (2018). Word knowledge and comprehension effects of an academic vocabulary intervention for middle school students. American Educational Research Journal, 55(3), 572-616. https://doi.org/10.3102/0002831217744181 
Merriam, S. B. (2009). Qualitative research: A guide to design and implementation. San Francisco, CA: Jossey-Bass.

Mokhtari, K., \& Velten, J. (2015). Strengthening academic vocabulary with Word Generation helps sixth-grade students Improve reading comprehension. Middle Grades Research Journal, 10(3), 23-42.

Monteiro, V., Mata, L., \& Peixoto, F. (2015). Intrinsic Motivation Inventory: Psychometric properties in the context of first language and mathematics learning. Psicologia: Reflexão e Crítica, 28(3), 434-443. https://doi.org/10.1590/1678-7153.201528302

Moore, B., Boardman, A. G., Smith, C., \& Ferrell, A. (2019). Enhancing collaborative group processes to promote academic literacy and content learning for diverse Learners through video reflection. SAGE Open, 9(3), 215824401986148. https://doi.org/10.1177/2158244019861480

Olinghouse, N. G., \& Wilson, J. (2013). The relationship between vocabulary and writing quality in three genres. Reading and Writing, 26(1), 45-65. https://doi.org/10.1007/s11145-012$9392-5$

Own, C.-M. (2018). Making without makerspace, another study of authentic learning with augmented reality technology. In T.-W. Chang, R. Huang, \& Kinshuk (Eds.), Authentic Learning Through Advances in Technologies, Lecture Notes in Educational Technology. 189-201. Springer Singapore. https://doi.org/10.1007/978-981-10-5930-8_11

Oxford, R. L. (1997). Cooperative learning, collaborative learning, and interaction: Three communicative strands in the language classroom. The Modern Language Journal, 81(4), 443-456. https://doi.org/10.1111/j.1540-4781.1997.tb05510.x 
Pajares, F. (2003). Self-efficacy beliefs, motivation, and achievement in writing: A review of the literature. Reading \& Writing Quarterly, 19(2), 139-158. https://doi.org/10.1080/10573560308222

Papavlasopoulou, S., Giannakos, M. N., \& Jaccheri, L. (2017). Empirical studies on the Maker Movement, a promising approach to learning: A literature review. Entertainment Computing, 18, 57-78. https://doi.org/10.1016/j.entcom.2016.09.002

Papert, S. (1993). The children's machine: Rethinking school in the age of the computer. BasicBooks.

Papert, S., \& Harel, I. (1991). Situating Constructionism. In S. Papert \& I. Harel (Eds.), Constructionism (pp. 1-11). Ablex.

Piaget, J. (1954). The construction of reality in the child. (M. Cook, Trans). New York, NY, US: Basic Books.

Plano Clark, V. L., \& Creswell, J. W. (Eds.). (2008). The mixed methods reader. Thousand Oaks, CA: Sage Publications.

Prain, V., \& Hand, B. (1999). Students perceptions of writing for learning in secondary school science. Science Education, 83(2), 151-162. https://doi.org/10.1002/(SICI)1098237X(199903)83:2<151::AID-SCE4>3.0.CO;2-S

Ray, A. B., Graham, S., Houston, J. D., \& Harris, K. R. (2016). Teachers use of writing to support students' learning in middle school: A national survey in the United States. Reading and Writing, 29(5), 1039-1068. https://doi.org/10.1007/s11145-015-9602-z

Revkin, A. C. (2009, April 27). Obama's call to create, not just consume. Dot Earth: New York Times Blog. https://dotearth.blogs.nytimes.com/ 
Rosenzweig, E. Q., \& Wigfield, A. (2016). STEM motivation interventions for adolescents: A promising start, but further to go. Educational Psychologist, 51(2), 146-163. https://doi.org/10.1080/00461520.2016.1154792

Ryan, R. M. (1982). Control and information in the intrapersonal sphere: An extension of cognitive evaluation theory. Journal of Personality and Social Psychology, 43(3), 450461. https://doi.org/10.1037/0022-3514.43.3.450

Saldaña, J. (2016). The coding manual for qualitative researchers (3E [Third edition]). Los Angeles, CA: Sage Publications.

Sampson, V., Enderle, P., Grooms, J., \& Witte, S. (2013). Writing to learn by learning to write during the school science laboratory: Helping middle and high school students develop argumentative writing skills as they learn core ideas. Science Education, 97(5), 643-670. https://doi.org/10.1002/sce.21069

Schlegel, R. J., Chu, S. L., Chen, K., Deuermeyer, E., Christy, A. G., \& Quek, F. (2019). Making in the classroom: Longitudinal evidence of increases in self-efficacy and STEM possible selves over time. Computers \& Education, 142, 103637. https://doi.org/10.1016/j.compedu.2019.103637

Schleppegrell, M. J. (2001). Linguistic features of the language of schooling. Linguistics and Education, 12(4), 431-459. https://doi.org/10.1016/S0898-5898(01)00073-0

Sheridan, K., Halverson, E. R., Litts, B., Brahms, L., Jacobs-Priebe, L., \& Owens, T. (2014). Learning in the making: A comparative case study of three makerspaces. Harvard Educational Review, 84(4), 505-531. https://doi.org/10.17763/haer.84.4.brr34733723j648u 
Slatter, D., \& Howard, Z. (2013). A place to make, hack, and learn: Makerspaces in Australian public libraries. The Australian Library Journal, 62(4), 272-284. https://doi.org/10.1080/00049670.2013.853335

Slavin, R. E. (1991). Synthesis of research on cooperative learning. Educational Leadership, $48(5), 71-82$.

Snow, C. E. (2010). Academic language and the challenge of reading for learning about science. Science, 328(5977), 450-452. https://doi.org/10.1126/science.1182597

Snow, Catherine E., \& Uccelli, P. (2009). The Challenge of Academic Language. In D. R. Olson \& N. Torrance (Eds.), The Cambridge Handbook of Literacy (pp. 112-133). Cambridge University Press. https://doi.org/10.1017/CBO9780511609664.008

Sofroniou, A., \& Poutos, K. (2016). Investigating the effectiveness of group work in mathematics. Education Sciences, 6(4), 30. https://doi.org/10.3390/educsci6030030

Stake, R. E. (1995). The art of case study research. Thousand Oaks, CA: Sage Publications.

Taylor, K., \& Baek, Y. (2018). Collaborative robotics: More than just working in groups. Journal of Educational Computing Research, 56(7), 17. https://doi.org/10.1177/0735633117731382

Tham, J. (2019). Multimodality, and the making of a maker pedagogy for technical communication and rhetoric (Doctoral dissertation). Retrieved from http://hdl.handle.net/11299/206361

The Current. (2013, July 10). Writers at work: Making and connected learning. The Current. https://thecurrent.educatorinnovator.org/resource/writers-at-work-making-and-connectedlearning 
Townsend, D. (2015). Who's using the language? Supporting middle school students with content area academic language. Journal of Adolescent \& Adult Literacy, 58(5), 376-387. https://doi.org/10.1002/jaal.374

Townsend, D., Filippini, A., Collins, P., \& Biancarosa, G. (2012). Evidence for the importance of academic word knowledge for the academic achievement of diverse middle school students. The Elementary School Journal, 112(3), 497-518. https://doi.org/10.1086/663301

Truckenmiller, A. J., \& Petscher, Y. (2019). The role of academic language in written composition in elementary and middle school. Reading and Writing. https://doi.org/10.1007/s11145-019-09938-7

Uccelli, P., Barr, C. D., Dobbs, C. L., Galloway, E. P., Meneses, A., \& Sánchez, E. (2015). Core academic language skills: An expanded operational construct and a novel instrument to chart school-relevant language proficiency in preadolescent and adolescent learners. Applied Psycholinguistics, 36(5), 1077-1109. https://doi.org/10.1017/S014271641400006X

Uccelli, P., Dobbs, C. L., \& Scott, J. (2013). Mastering academic language: Organization and stance in the persuasive writing of high school students. Written Communication, 30(1), 36-62. https://doi.org/10.1177/0741088312469013

Uccelli, P., Galloway, E. P., Barr, C. D., Meneses, A., \& Dobbs, C. L. (2015). Beyond vocabulary: Exploring cross-disciplinary academic-language proficiency and its association with reading comprehension. Reading Research Quarterly, 50(3), 337-356. https://doi.org/10.1002/rrq.104 
van Blankenstein, F. M., Saab, N., van der Rijst, R. M., Danel, M. S., Bakker-van den Berg, A. S., \& van den Broek, P. W. (2019). How do self-efficacy beliefs for academic writing and collaboration and intrinsic motivation for academic writing and research develop during an undergraduate research project? Educational Studies, 45(2), 209-225. https://doi.org/10.1080/03055698.2018.1446326

Vongkulluksn, V. W., Matewos, A. M., Sinatra, G. M., \& Marsh, J. A. (2018). Motivational factors in makerspaces: A mixed methods study of elementary school students' situational interest, self-efficacy, and achievement emotions. International Journal of STEM Education, 5(1). https://doi.org/10.1186/s40594-018-0129-0

Vroom, V. H. (1995). Work and motivation (1. ed). Jossey-Bass.

Wentzel, K. R. (1998). Social relationships and motivation in middle school: The role of parents, teachers, and peers. Journal of Educational Psychology, 90(2), 202-209. https://doi.org/10.1037/0022-0663.90.2.202

Wilczynski, V. (2015). Academic Maker Spaces and Engineering Design. 19. YOUmedia. (2015). Supporting organizations. YOUmedia Learning Labs Network. http://community.youmedia.org/about-the-cop/supportingorgs

Zhong, B., \& Wang, Y. (2019). Effects of roles assignment and learning styles on pair learning in robotics education. International Journal of Technology and Design Education. https://doi.org/10.1007/s10798-019-09536-2 


\section{Appendix A}

Role Assignments for Groups within Assigned Roles Subunits

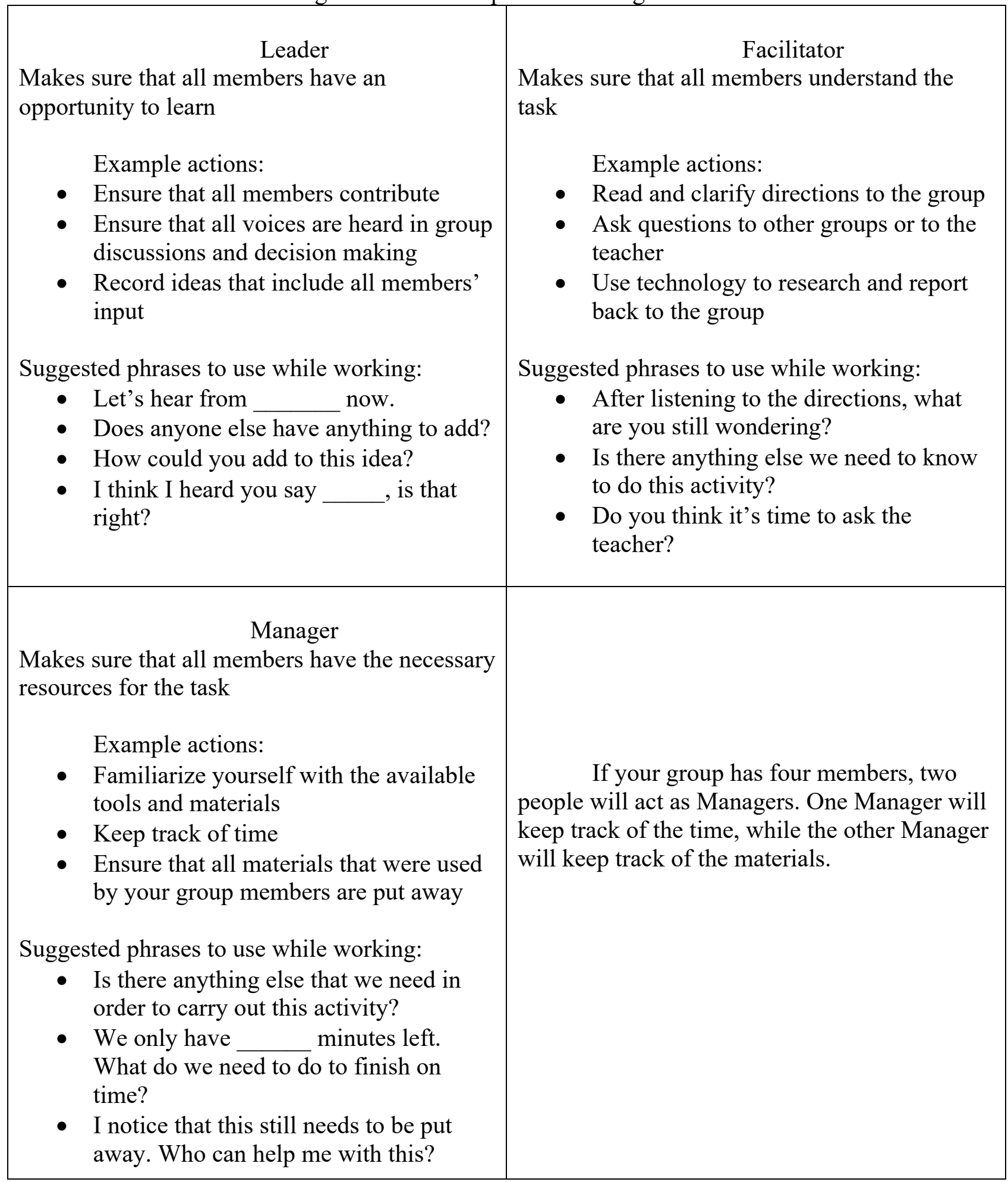




\section{Appendix B}

\section{Post-Survey}

For each of the following statements, please indicate how true it is for you, using the following scale:

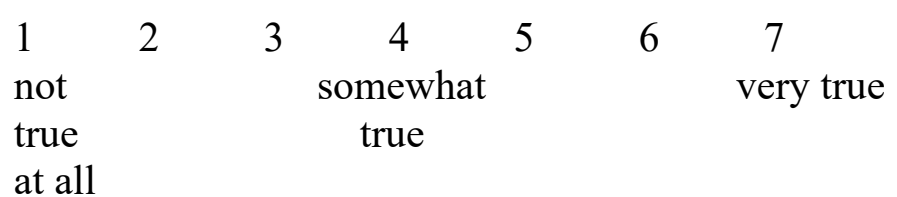

1. While I was working on the maker activities, I was thinking about how much I enjoyed them.

2. I did not feel at all nervous about doing the maker activities.

3. I felt that it was my choice to do the maker activities.

4. I think I was pretty good at the maker activities.

5. I found the maker activities very interesting.

6. I felt tense while doing the maker activities.

7. I think I did pretty well at the maker activities, compared to other students.

8. Doing the maker activities were fun.

9. I felt relaxed while doing the maker activities.

10. I enjoyed doing the maker activities very much.

11. I didn't really have a choice about doing the maker activities.

12. I am satisfied with my performance at the makers activities.

13. I was anxious while doing the maker activities.

14. I thought the maker activities were very boring. 
15. I felt like I was doing what I wanted to do while I was working on the maker activities.

16. I felt pretty skilled at the maker activities.

17. I thought the maker activities were very interesting.

18. I felt pressured while doing the maker activities.

19. I felt like I had to do the maker activities.

20. I would describe the makers activities as very enjoyable.

21. I did the maker activities because I had no choice.

22. After working at the maker activities for a while, I felt pretty competent. 


\section{Appendix C}

Interview Questions for Students by Subunits and Variables

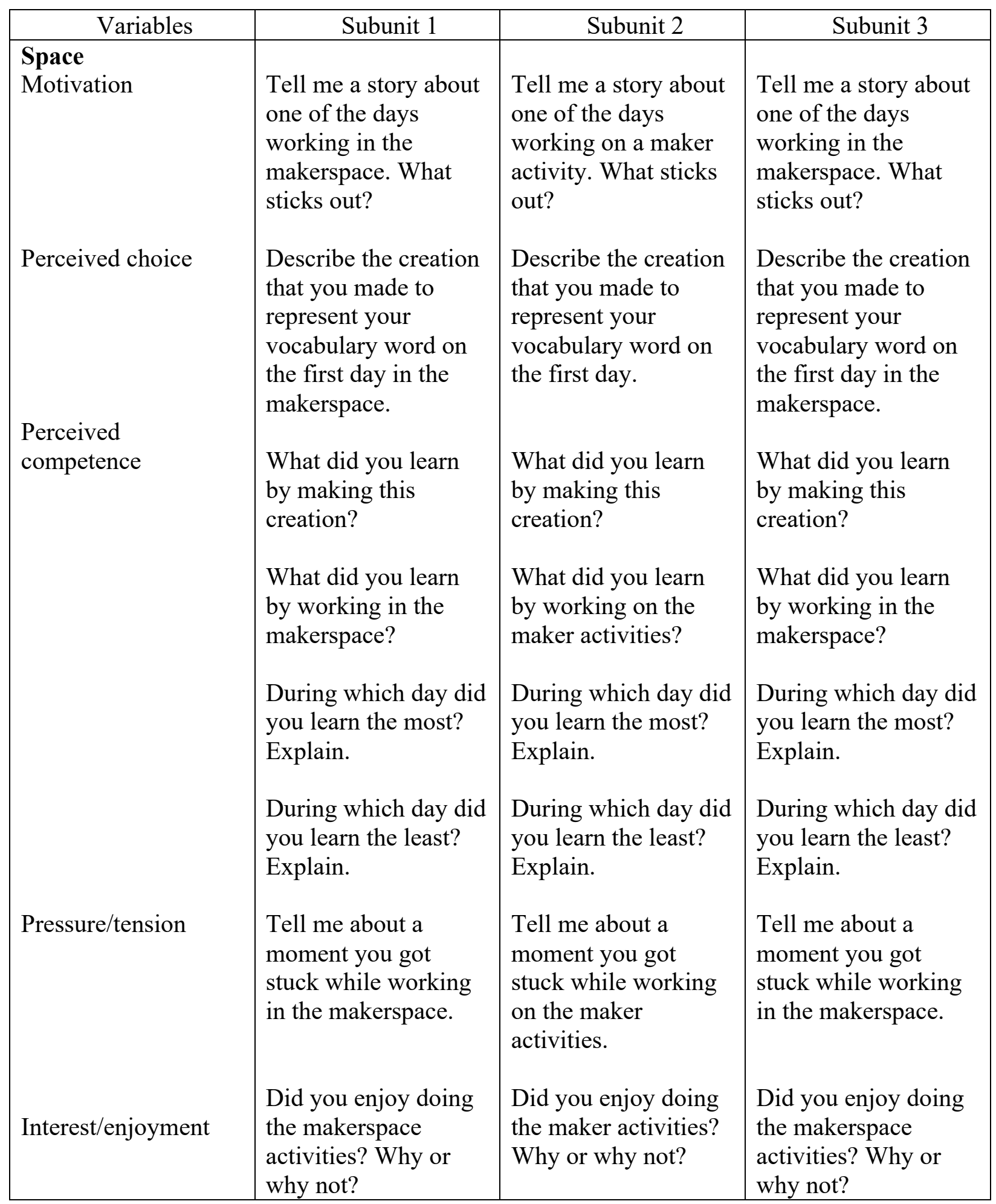




\begin{tabular}{|c|c|c|c|}
\hline $\begin{array}{l}\text { Space } \\
\text { Academic writing }\end{array}$ & $\begin{array}{l}\text { When you wrote your } \\
\text { final draft, how did } \\
\text { you refer to this } \\
\text { vocabulary word? } \\
\text { When you wrote your } \\
\text { final draft, how did } \\
\text { you refer to one or } \\
\text { any of the days } \\
\text { working in the } \\
\text { makerspace? }\end{array}$ & $\begin{array}{l}\text { When you wrote your } \\
\text { final draft, how did } \\
\text { you refer to this } \\
\text { vocabulary word? } \\
\text { When you wrote your } \\
\text { final draft, how did } \\
\text { you refer to one or } \\
\text { any of the days } \\
\text { working on the maker } \\
\text { activities? }\end{array}$ & $\begin{array}{l}\text { When you wrote your } \\
\text { final draft, how did } \\
\text { you refer to this } \\
\text { vocabulary word? } \\
\text { When you wrote your } \\
\text { final draft, how did } \\
\text { you refer to one or } \\
\text { any of the days } \\
\text { working in the } \\
\text { makerspace? }\end{array}$ \\
\hline $\begin{array}{l}\text { Collaboration } \\
\text { Motivation }\end{array}$ & $\begin{array}{l}\text { Tell me about your } \\
\text { experience working } \\
\text { in a group. }\end{array}$ & $\begin{array}{l}\text { Tell me about your } \\
\text { experience working } \\
\text { in a group. }\end{array}$ & $\begin{array}{l}\text { Tell me about your } \\
\text { experience working } \\
\text { in a group. }\end{array}$ \\
\hline Perceived choice & $\begin{array}{l}\text { Why did you choose } \\
\text { your role? }\end{array}$ & $\begin{array}{l}\text { Why did you choose } \\
\text { your role? }\end{array}$ & $\begin{array}{l}\text { How did you } \\
\text { contribute to your } \\
\text { group? }\end{array}$ \\
\hline $\begin{array}{l}\text { Perceived } \\
\text { competence }\end{array}$ & $\begin{array}{l}\text { How well do you } \\
\text { think your carried out } \\
\text { the responsibilities of } \\
\text { your role? Explain. }\end{array}$ & $\begin{array}{l}\text { How well do you } \\
\text { think your carried out } \\
\text { the responsibilities of } \\
\text { your role? Explain. }\end{array}$ & $\begin{array}{l}\text { How well do you } \\
\text { think you contributed } \\
\text { to your group? }\end{array}$ \\
\hline Pressure/tension & $\begin{array}{l}\text { Tell me about a time } \\
\text { that you faced a } \\
\text { challenge while } \\
\text { working with your } \\
\text { group members. }\end{array}$ & $\begin{array}{l}\text { Tell me about a time } \\
\text { that you faced a } \\
\text { challenge while } \\
\text { working with your } \\
\text { group members. }\end{array}$ & $\begin{array}{l}\text { Tell me about a time } \\
\text { that you faced a } \\
\text { challenge while } \\
\text { working with your } \\
\text { group members. }\end{array}$ \\
\hline Interest/enjoyment & $\begin{array}{l}\text { What was your role } \\
\text { in your group? Did } \\
\text { you like your role? } \\
\text { Why or why not? }\end{array}$ & $\begin{array}{l}\text { What was your role } \\
\text { in your group? Did } \\
\text { you like your role? } \\
\text { Why or why not? }\end{array}$ & $\begin{array}{l}\text { Did you like working } \\
\text { in your group? Why } \\
\text { or why not? }\end{array}$ \\
\hline $\begin{array}{l}\text { Collaboration } \\
\text { Academic writing }\end{array}$ & $\begin{array}{l}\text { How do you think } \\
\text { working in a group } \\
\text { affected your writing } \\
\text { revisions process? } \\
\text { How do you think } \\
\text { working in a group }\end{array}$ & $\begin{array}{l}\text { How do you think } \\
\text { working in a group } \\
\text { affected your writing } \\
\text { revisions process? } \\
\text { How do you think } \\
\text { working in a group }\end{array}$ & $\begin{array}{l}\text { How do you think } \\
\text { working in a group } \\
\text { affected your writing } \\
\text { revisions process? } \\
\text { How do you think } \\
\text { working in a group }\end{array}$ \\
\hline
\end{tabular}




\begin{tabular}{|l|l|l|}
\hline $\begin{array}{l}\text { affected your final } \\
\text { draft? }\end{array}$ & $\begin{array}{l}\text { affected your final } \\
\text { draft? }\end{array}$ & $\begin{array}{l}\text { affected your final } \\
\text { draft? }\end{array}$ \\
\hline
\end{tabular}

Questions for all subunits not directly related to independent variables:

Tell me what you think about writing in general.

Tell me what you think about writing in science class.

Describe your experience writing your first draft.

Describe your experience writing your final draft.

How would you compare your first draft to your final draft?

Describe any challenges that you encountered when you wrote either draft. 


\section{Appendix D \\ Interview Questions for Teacher}

Space- Motivation

1. What were some similarities you noticed regarding students working in the makerspace and the classroom? Any differences?

Perceived choice

2. Out of the three subunits, in which one were students the most autonomous? Which was the least? Why do you think that is?

Perceived competence

3. In which subunit do you think students seemed the most confident in carrying out the maker activities? In which did they seem they least confident? What makes you think this?

Pressure/tension

4. Out of the three subunits, in which did students to face the most challenges during the making activities? In which did they face the least? Why do you think that is?

Interest/enjoyment

5. Which space do you think students preferred — the makerspace or classroom? What makes you think that?

6. In which space do you prefer to teach and why?

Space- Writing

7. How do you think each space affected students' final writing product? Collaboration- Motivation

8. Describe how your students typically collaborate in your class. 
Perceived choice

9. Out of the three subunits, in which did students collaborate the most effectively? In which did they collaborate the least effectively? Why do you think that is?

Perceived competence

10. How did students seem confident or lacking confidence in working in groups?

Pressure/tension

11. In terms of working as a group, what were some challenges that students faced? Did you notice any differences or similarities among the three subunits?

Interest/enjoyment

12. From your observations, did students enjoy working in groups? Which subunit seemed to enjoy group the most? The least?

Collaboration- Writing

13. When students revised their writing, did they seem to work together or separately? Did this vary by subunit?

Writing

14. From your standpoint, what are students' general attitudes toward writing in science class?

15. What seems to be their writing strengths? Weaknesses?

16. What is the approach you take toward teaching writing in science?

17. As a teacher, what are your strengths in teaching writing? Weaknesses?

18. What were differences and similarities that you observed when students wrote their first and final drafts? 